\title{
RECENT ADVANCES IN OCCUPATIONAL AND ENVIRONMENTAL HEALTH HAZARDS OF WORKERS EXPOSED TO GASOLINE COMPOUNDS
}

\section{CHRISTOPHER E. EKPENYONG and ASUQUO E. ASUQUO}

\author{
University of Uyo, Uyo, Nigeria \\ Faculty of Basic Medical Sciences, Department of Physiology
}

\begin{abstract}
The impact of health and environmental hazards, associated with the constituents of gasoline, on occupationally exposed workers has been recorded over the past few decades. However, the scientific literature on their pathogenic potential remains incomplete, which could affect the current understanding of the associated health risks. This review provides current information based on recently improved research techniques to evaluate gasoline toxicity profiles for humans. Our current knowledge provides insight into the intricate mechanism of gasoline-induced adverse effects, including the formation of reactive metabolites via bio-activation and subsequent generation of reactive oxygen species (ROS) and oxidative stress, which are involved in multiple mechanisms that are central to the aetiology of gasoline-induced toxicity. These mechanisms include covalent binding to deoxyribonucleic acid (DNA), leading to oxidative damage, tumor-suppression gene activity, and activation of pro-oncogenes. Furthermore, it results in induction of autoimmunity and local inflammatory responses, disruption of multiple neurotransmitters and immune cell function, derangement of various enzyme activities (e.g., sodiumpotassium adenosine triphosphate $\left(\mathrm{Na}^{+} / \mathrm{K}^{+} /\right.$ATPase) activity, cytochrome P450 (CYP450), nitric oxide synthase (NOS), antioxidant enzyme activities, etc.), conjugation of bile, and non-specific cell membrane interaction, leading to damage of the membrane lipid bilayer and proteins. Available data suggests that exposure to gasoline or gasoline constituents have the potential to cause different types of illnesses. The data highlights the need to maintain safety measures via suitable research, medical surveillance, regulatory control, life style modification, early detection, and intervention to minimize exposure and manage suspected cases. They also present novel opportunities to design and develop effective therapeutic strategies against gasoline-induced detrimental effects. Int J Occup Med Environ Health 2017;30(1):1-26
\end{abstract}

Key words:

Oxidative stress, Exposure, Toxicity, Gasoline, Humans, Reactive metabolite

\section{INTRODUCTION}

Increased health and safety risks have characterized most occupations worldwide. The impact is felt more in the case of some occupations and occupational environments than others, causing some workers to leave the labour market permanently before reaching retirement age. Workers around the world are faced with various kinds of workplace hazards [1], including but not limited to psychosocial, biological, physical, and chemical agents. The causal role that occupational exposure plays in the pathogenesis of disease, injury, and premature death have been recorded in many early writings of man. Hippocrates recommends

Received: September 15, 2015. Accepted: May 19, 2016.

Corresponding author: C.E. Ekpenyong, University of Uyo, Faculty of Basic Medical Sciences, Department of Physiology, Ikpa Road, Uyo, Akwa Ibom State, P.M.B 1017, Nigeria (e-mail: chrisvon200@yahoo.com, chrisvon300@yahoo.com). 
enquiry into patients' occupational history while trying to establish causality.

Besides human health per se, work-related ill-health has a significant negative economic impact. According to the International Labour Organization [2], at least 2 million of the estimated 2.7 billion workers die every year from work-related ill-health and injuries, about 160 million people suffer from work-related diseases (WRDs), and about 270 million fatal and non-fatal work-related accidents occur each year [2]. Additionally, about 4\% of the world's annual gross domestic product (GDP) (1.25 trillion dollars) is lost because of work-related health concerns. Work-related ill-health caused by exposure to chemical agents (organic solvents) has become a major concern in the workplace [3].

Epidemiological data indicates that petrochemical industries provide an exposure scenario that increases the vulnerability of workers to gasoline-related health risks [4]. Over the years, there has been a global increase in petrochemical firms, including the emergence of many gasoline stations, to meet the increasing demands of a fast-growing population and because of globalization, urbanization, and accelerated economic development. Furthermore, there is a concomitant increase in the number of individuals serving as full-time gasoline stations service attendants who spend a full work-day exposed to gasoline vapors from different sources, including losses from underground tanks, displacement vapor, losses from filler pipes during refueling, fuel spillage, and evaporative and exhaust pipe emissions from motor vehicles.

Gasoline is a complex mixture of hydrocarbons and additives, including short-chain organic compounds, lightchain volatile compounds, and heavy-chain hydrocarbons [4]; however, the relative concentration of gasoline components is dependent upon the crude oil source, refinery process, and production lines used.

Toxicological studies indicate that the light-chain volatile compounds (benzene, toluene, ethylbenzene, and xylene (BTEX)) are the components most toxic to humans [4]. They constitute the volatile fractions of gasoline that are gradually released into the air and may exist in both the vapor phase and the water-soluble fraction, due to their high vapor pressure and water solubility.

Benzene is designated as the most important and toxic chemical of the BTEX compounds [4]. Workers may be exposed intentionally or accidentally through inhalation, ingestion, or via dermal routes. Petrol pump attendants and workers in the petrochemical industries in developing countries are particularly vulnerable to the hazardous effects of gasoline constituents because they have to manipulate the fuel and as a result inhale fuel vapors during daily work due to the lack of adequate regulatory and protective mechanisms [5]. During refueling at service stations, the vapor-saturated air is expelled through the filling channel around the nozzle, and into the breathing zone of the service attendant filling the tank. This exposure process is repeated as many times as the attendant fills a tank during a work shift and it is further exacerbated by the non-usage of personal protective equipment. These hydrocarbons are readily absorbed and may cause a wide range of adverse health effects. Such effects may vary depending on several factors, including differences in exposure intensity and duration [6], chemical and molecular properties of the gasoline, as well as inter-individual differences, due to variation in individuals' pharmacodynamics and pharmacokinetics related to the different gasoline components [7]. Since each of the BTEX compounds has an inherent toxic potential, workers at gasoline stations are the population at greatest risk of being simultaneously exposed to the synergistic and/or additive adverse effects of the gasoline constituents.

Although the health and environmental hazards of gasoline had been previously documented through epidemiological and experimental studies over the past several decades [8], most of the study designs were outdated and thus were not conducted with contemporary fuels [9]. 
Moreover, many of the biological assays were not conducted on contemporary inhalation exposures to gasoline. Most of the hazards and exposure data from these studies was not characterized at the level of detail that would be considered adequate today [9]. More so, reports of human data are rare, and the scattered available research information may not be accessible to those at risk.

Recently improved research techniques and exposure assessment measures, as well as reformulation of gasoline blends to avoid the harmful heavy metal additives and noxious constituents, such as lead and benzene [10], have improved the quantity and quality of data in research literature, and provide new and interesting results. Some studies provided already known facts, while others reported non-significant information, yet other studies reported that exposure led to adverse health effects, which has generated controversial scientific issues [11], suggesting the need for up-to-date review information on the workrelated ill health of gasoline service station attendants, globally.

Therefore, this toxicological review document intends to provide at-a-glance information to the gasoline exposed workers and the general public on the global perspective and recent advances regarding the adverse systemic health effects associated with exposure to gasoline compounds. There is not the least doubt that the evolving understanding of gasoline-induced adverse health effects may have implications for potential therapies and preventative measures toward minimizing exposure, and hence risk, in the workplace.

\section{TOXICOKINETICS}

Since gasoline is a mixture of several hydrocarbon compounds and additives, different metabolic/toxicokinetic pathways are reported for the different compounds in the mixture. Nevertheless, gasoline is readily absorbed when inhaled or ingested. Absorption is followed by uptake and distribution in the body. A small percentage is

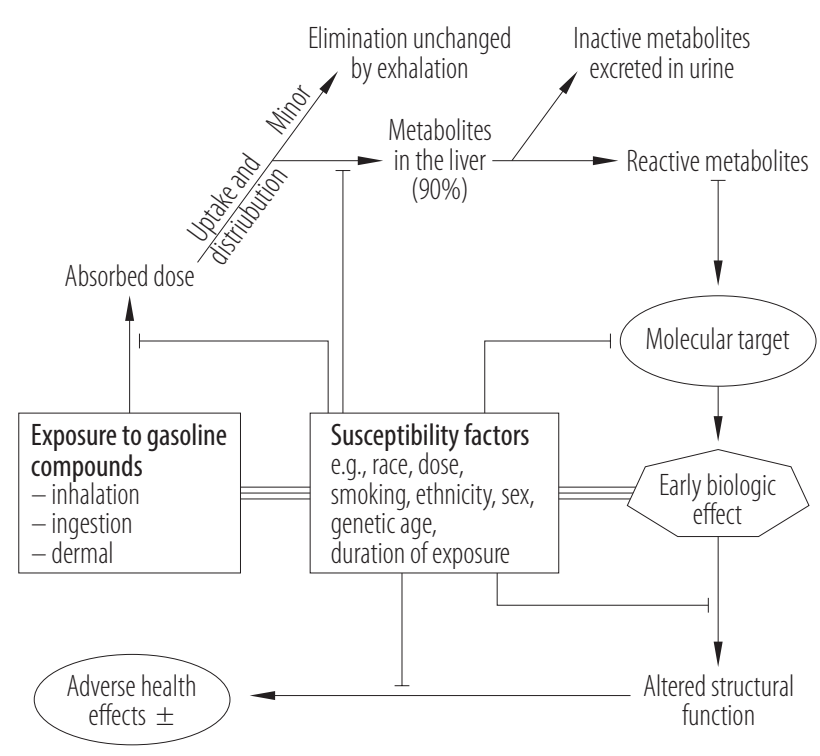

Fig. 1. Toxicokinetic pathway of gasoline compounds for exposed workers, and the modulatory effects of individual's susceptibility factors

eliminated either unchanged in exhaled air or as inactive metabolites in the urine, following metabolism in the liver. The active metabolites undergo further toxicokinetic processes, such as generation of reactive oxygen species, oxidative tissue damage, leading to altered structure and functions, and multi-system toxicity. Empirical data indicates that the toxicokinetic properties of different gasoline compounds may be modified by individual susceptibility factors, such as genetics, exposure concentration and duration, age, gender, race, and ethnicity (Figure 1).

\section{PHARMACODYNAMICS AND SYSTEMIC TOXICITY}

Recent advances in biological assays and in toxicity testing have provided greater insights into the health and environmental hazards of gasoline exposure in humans.

Accumulated evidence indicates that acute and long-term exposure to gasoline compounds may be associated with several systemic health effects, including hematological, respiratory, reproductive, immunological, dermatological, renal, and central nervous system pathologies in humans. Others include hepatotoxicity, genotoxicity, and 


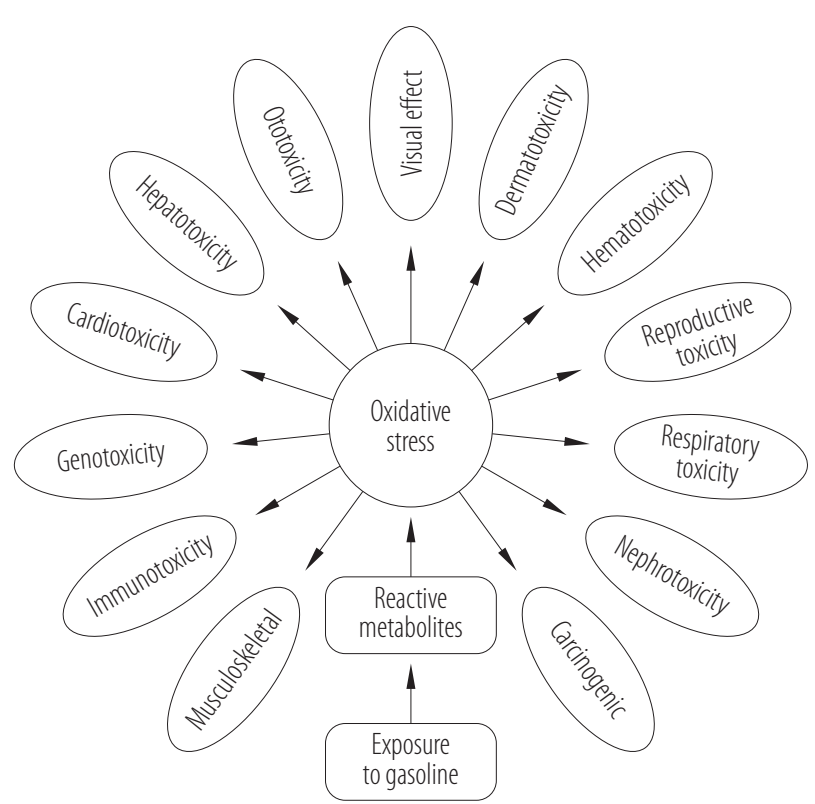

Fig. 2. Multi-systemic toxicity profile of gasoline compounds for exposed workers

carcinogenic potential (Figure 2). Cases of death following the inhalation of high concentrations of gasoline vapor have also been reported [12-14].

Many of the toxicological effects associated with exposure to gasoline have also been identified for one or more of the components of the mixtures. Although most studies have not described the exact composition of the mixture used, available data suggests that some gasoline (BTEX) compounds may be present in concentrations higher than their threshold-limit value (TLV), thereby causing effects that surpasses those of other constituents. However, it is noteworthy that the toxicity profile of some gasoline mixtures may remain high, even at a low concentration, probably due to differences in toxic kinetic properties of the different constituents [15].

The high blood/air partition coefficient as well as the more rapid perfusion and absorption rate of BTEX compounds, as compared to other gasoline constituents, may partly explain the high toxicity potential of BTEX compounds. This premise could also explain the high toxicity potential of benzene as compared to other BTEX compounds.
According to Azari et al. [4], gasoline service station attendants are more exposed to health-risks associated with benzene than to other compounds. Benzene biomonitoring of gasoline service station attendants should receive attention during medical surveillance of workers [16,17].

\section{Hematoxicity}

Several epidemiological studies [6,16-21] have established a close association between exposure to gasoline compounds and hematoxicity for humans. Although the reports of its effects on specific blood cells have been somewhat inconsistent, gasoline hematoxicity appears to be a constant feature and has been observed even at levels previously considered harmless to humans [22-24].

Accordingly, Okoro et al. [20] observed time-dependent significant decreases in red blood cell (RBC) count, white blood cell (WBC) count, hemoglobin (Hb), mean corpuscular concentration (MCHC), mean cell volume (MCV), and mean cell hemoglobin (MCH) among 200 exposed gasoline station workers at Calabar. A recent study by Ajugwo et al. [6] in Elele in Nigeria made a similar observation. Likewise, studies by Qu et al. [19] and Aleemuddin et al. [25] showed significant decreases in RBC, WBC and neutrophil counts among workers exposed to gasoline compounds. Arguing against these findings, Sahb [16] and Akintonwa et al. [26] found no association between exposure to gasoline compounds and hematoxicity.

These discrepant findings should be viewed in the light of the fact that other potential confounding factors, such as variation in assessment measures, individual variation (e.g., physical activity status, body mass index (BMI), partition coefficient between air and blood, and perfusion rate), and exposure to additional compounds, such as toluene, may have an impact on the results. For instance, while in some studies [27-29] co-administration of toluene reduced benzene hematoxicity, others [30] showed that the presence of toluene in a toluene-benzene mixture significantly worsened the adverse effect of benzene 
on lymphocytes. It is noteworthy that such interaction may depend on the relative concentration of benzene and toluene in the mixture [31].

The mechanisms underlying gasoline hematoxicity may in part stem from the myelosuppressive effect of the various gasoline constituents. Benzene, for instance, has been designated as the most hematoxic gasoline (BTEX) constituent in humans. Several mechanisms underlying benzene hematoxicity have been postulated by various investigators, which include, but are not limited to the following: interference with cell-cycle regulation or expression of deoxyribonucleic acid (DNA)-damage/repair-related genes, oxidative stress genes, growth factor-related genes, oncogenes, and hemopoiesis-related genes.

Occupational exposure to benzene has been shown to cause degeneration of the bone marrow, aplastic anaemia, and leukaemia, owing to its radiomimetic properties [32,33]. Specifically, benzene exposure is posited to cause suppression of the cell cycle by p53-mediated over-expression of $\mathrm{p} 21$, a cyclin-dependent kinase, with resultant changes in the dynamics of erythropoiesis [18], including a decrease in growth maturation of pleuripotential stem cells (colony-forming unit spleen - CFU-S) and lineage-restricted stem cells (colony-forming units granulocyte, monocyte - GM-CFUs), progenitor cells in various stages of maturation, and stromal cells that provide growth factors necessary for bone marrow function.

Furthermore, exposure to gasoline inhalation may lead to the metabolic activation of some of its constituents (such as benzene) to form active metabolites (hydroquinone and 1,2,4-benzentriol) by a cytochrome P450 2E1-enzyme (CYP2E1)-dependent mechanism. These metabolites are known to induce oxidative stress that triggers myelotoxicity and hematoxicity in many ways, including depletion of cellular levels of glutathione (GSH), involvement of redox cycling, and generation of reactive oxygen species (ROS) that may react with macromolecules, such as membranes, enzymes, and deoxyribonucleic acid (DNA) in the target tissue. Additionally, oxidative stress is associated with increased vulnerability of the RBCs to destruction, and hence with anaemia (Figure 3) [34].

One study [35] found a strong correlation between the 4 benzene urine metabolites and hematological outcomes among the exposed workers; catechol, for instance, was found to be strongly associated with the MCV, a measure of the RBC toxicity, whereas hydroquinone showed a strong correlation with the absolute lymphocyte count. Complete blood count as well as differentials,

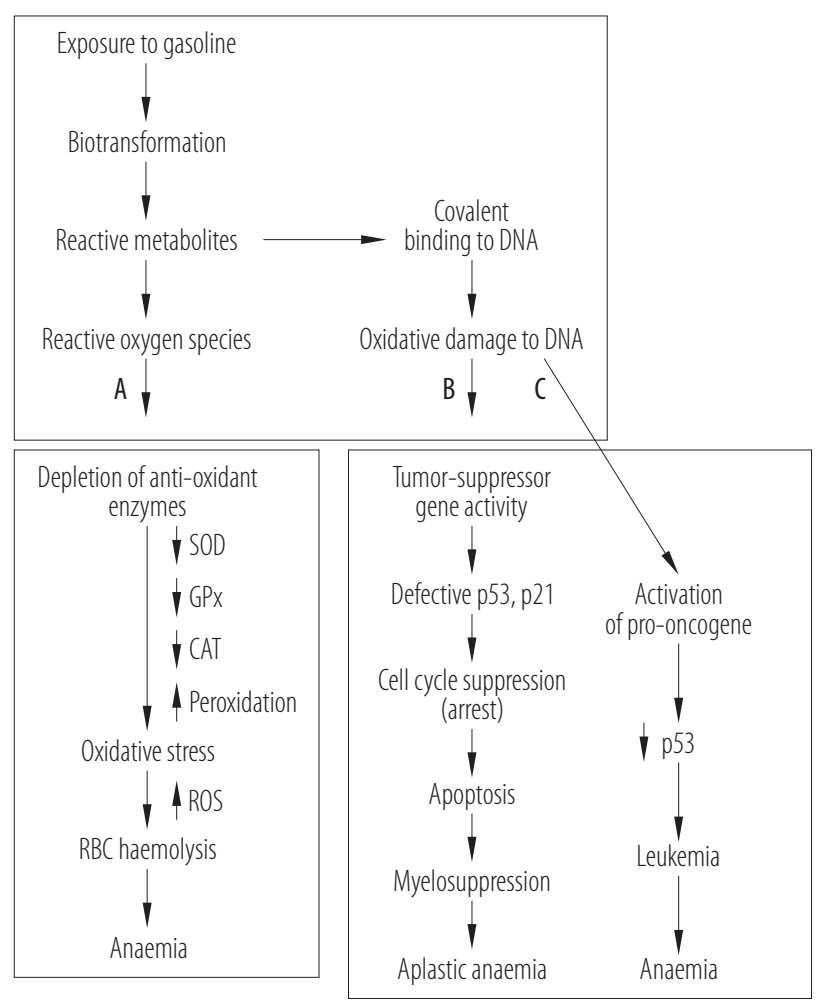

DNA - deoxyribonucleic acid; SOD - superoxide dismutase; GPx - glutathione peroxidase; CAT - catalase; ROS - reactive oxygen species; RBC red blood cell; p53 - a 53-kilodalton protein; p21 - a 21-dalton protein. Reactive metabolites generated by the biotransformation of inhaled gasoline compounds may either cause anaemia via oxidative damage to RBC (A), or covalent binding to DNA may cause tumor-suppressive effects with resultant cell-cycle suppression, apoptosis, myelosuppression, and aplastic anaemia (B). Alternatively, oxidative damage to DNA may result in activation of pro-oncogenes, suppression of p53, and leukemia (C).

Fig. 3. Mechanisms of gasoline-induced hematoxicity 
and the absolute lymphocyte count in particular, is recommended when monitoring workers for early biological effects of benzene exposure and identification of occupational environments associated with increased risk of subsequent development of hematopoietic malignancies [35]. In a study of 150 subjects (50 petrol station attendants (PSA), 50 automobile mechanics (AM), and 50 control subjects), Udonwa et al. [21] found that exposure to gasoline vapor by the PSA and AM was associated with a timedependent increase in blood methaemoglobin (MetHb) concentration, as compared to the controls. Methaemoglobin is an abnormal hemoglobin $(\mathrm{Hb})$, in which the iron molecule is in the ferric $\left(\mathrm{Fe}^{3+}\right)$ rather than the ferrous $\left(\mathrm{Fe}^{2+}\right)$ state. With $\mathrm{Fe}^{3+}$, the oxygen-carrying capacity of $\mathrm{Hb}$ is impaired and, depending on the severity, the affected individual may present with several clinical symptoms, including headache, cyanosis, fatigue, coma, and death.

\section{Reproductive toxicity}

Recent research has indicated that gasoline and its compounds (BTEX) are reproductive toxicants with the potential to cause adverse effects on male [36] and female $[7,37,38]$ reproductive systems. As a reproductive toxin, it may cause changes in sexual behavior, disordered menstrual patterns and sex hormone profiles [7], decreased fertility, as well as interference with fetal development [39].

$\mathrm{Xu}$ et al. [37] reported increased risk of spontaneous abortion among 3000 women employed in a Chinese petrochemical plant, particularly those exposed to benzene and gasoline. A large prospective study of 792 female workers by Chen et al. [38] found that pregnant workers in the petrochemical industry had a significant positive correlation between exposure to gasoline and reduction in birth weight. The association was significant even at exposure to a concentration as low as less than $1 \mathrm{ppm}$ ( 5 times below the limit recommended by the Occupational Safety and Health Administration (OSHA)). A study by
Slama et al. [39] also reported that exposure to benzene is associated with intrauterine growth retardation (IUGR). According to Hatch et al. [40], exposure to polycyclic aromatic hydrocarbons (PAHs) caused increased risk of cytogenetic alterations and mutagenic effects in both somatic cells and in embryonic tissues.

One animal study [41] reported a structural disruption in the uterus, fallopian tubes, and ovaries in female, as well as spermatocytic arrest in male rats acutely exposed to gasoline inhalation. The authors also reported a significant reduction in levels of both male and female reproductive hormones.

A correlative study among female gasoline station workers documented a significant association between exposure to gasoline and disorders of menstrual patterns and reproductive hormone profiles; more specifically, serum levels of oestradiol were persistently low, while fluctuation in serum progesterone, follicle-stimulating hormone (FSH), luteinizing hormone ( $\mathrm{LH})$, and prolactin levels were observed. Disturbance of both cycle length and quantity of menstrual flow was also noted [7].

Several studies have found a correlation between ovarian hypo- and hyperplasia, as well as a reduction in the duration of the luteal phase of the menstrual cycle and exposure to gasoline compounds, particularly benzene [38,42]. Benzene impairs the release of oestradiol prior to ovulation and the release of progesterone at the early luteal phase, as well as that of FSH at the early follicular phase [38]. Xylene decreases plasma levels of progesterone and oestradiol whereas toluene increases the incidence of maternal and fetal morbidity and embryonic malformation. It reduces the hypothalamic level of gonadotropin-releasing hormone $(\mathrm{GnRH})$ and plasma gonadotropin levels $[43,44]$. Occupational exposure to BTEX compounds also causes poor semen quality [45].

The underlying mechanism by which benzene affects birth weight is posited to include suppression of rapidly growing cells (e.g., bone marrow cells), initiation of oxidative 
damage in the cells, and suppression of growth by its metabolites [46,47].

One animal study suggested that the induction of oxidative cell injury was the major pathophysiologic mechanism in the reproductive toxicity of toluene. Burmistrov et al. [48] showed that toluene induced an increase in the activities of oxidative stress-related enzymes (glutathione and catalase) and the intensity of lipid peroxidation in ovarian tissues, leading to oxidative ovarian cell damage.

Sirotkin et al. [43] demonstrated the induction of ovarian cell apoptosis, proliferation, turnover, and release of peptide and steroid hormones and growth factors as the plausible mechanisms underlying the reproductive toxicity of BTEX compounds. However, other studies have suggested that BTEX compounds may exert their effects at the level of the hypothalamic-pituitary axis. Toluene and xylene have been found to cause a significant reduction in serum levels of GnRH, GnRH-receptors and pituitary-1 messenger ribonucleic acid (mRNA) in experimental animals [7,49].

\section{Respiratory toxicity}

In developing as well as some developed countries where the gasoline vapor recovery system (GVRS) is not commonly used at service stations, service station attendants and customers are directly exposed to inhaling a significant volume of the vapor discharged from the tank into their breathing zone; inhalation of fumes while refueling automobiles therefore becomes the main source of human exposure to gasoline [50]. When inhaled, gasoline vapor is readily absorbed and may cause significant respiratory function impairment [51-57].

Recent findings have shown that gasoline vapor and its constituents may cause considerable damage to the respiratory system, and affect both the upper and lower airway tract. It may irritate the mucous membrane, initiate local inflammatory changes with associated pulmonary congestion, oedema, and acute exudative tracheobronchitis.
Besides being the major route of human exposure [50], the respiratory tract is highly vulnerable to gasoline toxicity, due to its high accessibility and excellent absorption surface, which ensures that the hydrocarbons of gasoline are readily absorbed by the lungs $[58,59]$.

Evidence of restrictive [51,60-62] and/or obstructive [6365] airway perturbation, or both, have been reported among exposed persons. However, most studies report a restrictive type of lung function impairment $[52,55,60,62,66]$.

Extensive data has shown that most gasoline station workers show a decline in their lung function capacities and volumes (tidal volume (TV), forced vital capacity (FVC), forced expiratory volume in 1 second $\left(\mathrm{FEV}_{1}\right)$, maximum ventilatory volume (MVV), and forced expiratory flow $\left(\mathrm{FEF}_{25-75 \%}\right)[51,53,56]$ and symptoms such as chronic cough, wheezing, breathlessness, throat congestion, redness of eyes, headache, nausea, and vomiting have been reported upon exposure to these pollutants [67].

Sinha and Patil [57] used a cross-sectional study design to compare various lung function indices in 60 gasoline station workers with those of 50 unexposed participants, in Karad City, India. The authors noted a statistically significant reduction in $\mathrm{FVC}$, and $\mathrm{FEV}_{1}$, and $\mathrm{MVV}$ among the exposed compared to the unexposed group. Similar to most other studies [54], their study findings were suggestive of restrictive lung function impairment.

Begum and Rathna [52] reported consistent findings among 28 non-smoking males working at petrol stations in Mysore City, India. Aprajita et al. [66] in their study reported a significant decline in values of $\mathrm{FVC}, \mathrm{FEV}_{0.5}$, $\mathrm{FEV}_{1}, \mathrm{FEV}_{3}, \mathrm{FEF}_{50 \%}, \mathrm{FEF}_{25-75 \%}$, and peak expiratory flow rate (PEFR) in petrol pump workers.

The pathophysiological mechanisms underlying gasolineinduced respiratory function impairment have been postulated to include induction of the local inflammatory response along the airway, and/or oxidant/antioxidant imbalance by gasoline and its component metabolites, respectively (Figure 4). 


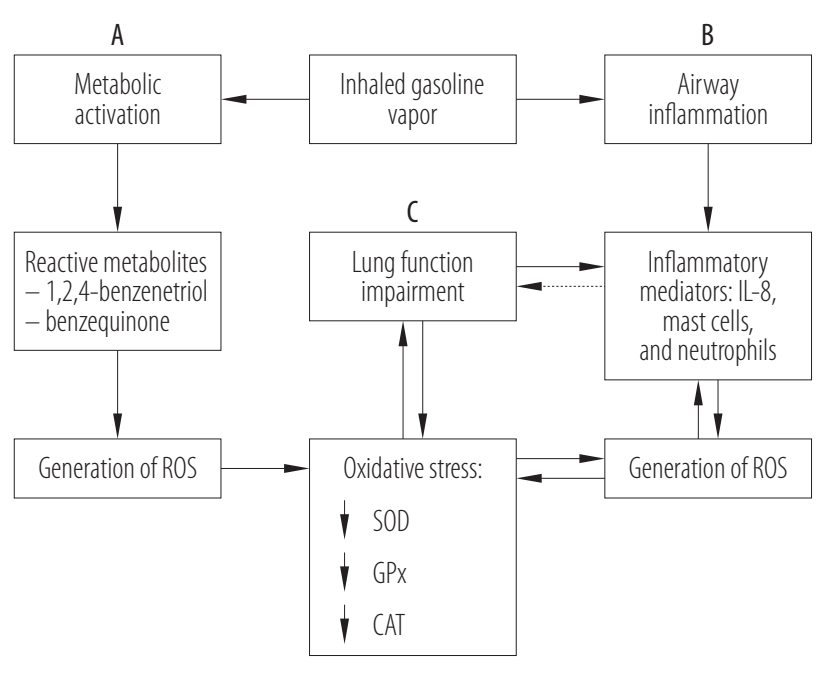

IL-8 - interleukin-8.

Other abbreviations as in Figure 3.

Pathways of gasoline-induced respiratory function impairment: A - reactive metabolites generated by the oxidative metabolism of gasoline compounds via a series of signaling mechanisms generate reactive oxygen species (ROS), causing oxidative stress and lung function impairment;

B - inhaled gasoline induces local inflammatory processes that result in the release of inflammatory mediators and ROS, and induces oxidative stress;

$\mathrm{C}$-reciprocal influence between gasoline-induced oxidative stress and inflammation in the pathogenesis of respiratory disease.

Fig. 4. Mechanisms of gasoline-induced respiratory function impairment

Many gasoline constituents, particularly the BTEX compounds, are known respiratory mucosal irritants. According to local inflammation theory, chronic or over-exposure to gasoline/diesel fumes leads to chronic inflammation of the respiratory tract and the lung parenchyma [68], pulmonary congestion, oedema, and exudative tracheobronchitis. In support of this hypothesis, Behndig et al. [69] demonstrated increased markers of airway inflammatory and antioxidant response mechanisms (increased mucosal neutrophils, mast cells, and levels of interleukin-8 (IL-8), myeloperoxidase (MPO), glutathione, and urate) in 18 study participants exposed to $100 \mu \mathrm{g} \times \mathrm{m}^{-3}$ diesel exhaust fumes for $18 \mathrm{~h}$. Their study findings were consistent with those of a previous study by
Wooden et al. [70], who found that workers exposed to fuel experienced upper-airway inflammation, as evidenced by significant increases in MPO, IL-8, and nasal fluid vanadium levels.

In one study [60], a 6-week daily exposure of animals to gasoline inhalation caused extensive histological changes to the epithelial cell lining of the bronchioles, including dilatation of the smooth endoplasmic reticulum, loss of secretory granules in the Clara cells, loss of ciliated cells, prominent nuclear alterations, necrotic type II pneumocytes, degeneration of the mitochondria, as well as some neoplastic changes. Grebic et al. [71] studied the effect of intermittent exposure of mouse lungs to gasoline vapor on metallothioneins (MT) (MT-I and MT-II), proteins involved in cellular protection against ROS, genotoxicity, and apoptosis. Upregulation of MT-I/II was observed in the lungs, central nervous system, and kidney tissues, as a protective action against ROS from gasoline.

Gasoline metabolites (benzequinone and 1,2,4-benzenetriol) are potent inducers of the ROS, creating an imbalance of oxidant/antioxidant molecules, and hence oxidative stress, similar to the effect of a local inflammatory response. Evidently, the local inflammatory and antioxidant response mechanisms are complementary, since oxidative stress and inflammation have reciprocal influences on each other in respiratory disease (Figure 4) [72].

\section{Neurotoxicity}

Gasoline-induced neurotoxicity has attracted a significant research interest worldwide. Many collaborative human and animal studies have linked exposure to gasoline to an increased risk for neuropsychological symptoms and mood disorders [73-75].

Many constituents of gasoline (BTEX) are known neurotoxins [76,77], and over-exposure may damage the central nervous system (CNS) [78], causing depression [78], facial flushing, ataxia, vertigo, mental confusion, dizziness, giddiness, nausea, weakness, headache, 
blurring of vision, slurred speech, difficulty in swallowing, and in some cases, coma and death may ensue within seconds. Survivors may sustain irreversible brain damage. A study by Rosenberg et al. [79] found evidence of persistent abnormal brain activities upon magnetic resonance imaging (MRI) 18 months after withdrawal from solvent exposure. Gasoline station workers are at a high risk and reports indicate cases of impaired intellectual capacity, and psychomotor and visual-motor functions. More immediate and delayed memory and increased mortality from mental disorders have been reported among gasoline workers than among controls [76,80-82].

A recent study by Tunsaringkarn et al. [83] found that the most prevalent symptoms reported by gasoline service station attendants were headache, fatigue, and throat irritation. This study supported previous work that showed that tanker drivers with long-term exposure to gasoline vapor developed a significant high-fatigue scale, headache, dyspnoea, irritation in the throat, dizziness, nausea, and saliva excretion compared to control [77].

The link between the neurotoxic effects of gasoline and the presence of these symptoms has been well established $[84,85]$. However, it is noteworthy that the clinical presentation may be dose- and/or exposure-duration-dependent, after adjusting for other covariates. For instance, a study assessing the potential dose-dependent neurotoxic effects of xylene and toluene showed that inhalation of xylene at an air concentration of above 90 ppm caused reduced reaction time and manual dexterity, disruption of body balance, and changes in the electroencephalogram (EEG). These effects were absent at concentrations below 90 ppm. At 300 ppm, reaction time, memory span, and the critical flicker fusion test were affected [86] whereas exposure at 100-400 ppm is associated with impairment of body balance and increased reaction time [87]. In a parallel study, occupational exposure to toluene at 100-150 ppm was associated with short-term memory loss, reduced manual dexterity, and reduced vigilance scores whereas at $75 \mathrm{ppm}$ these changes were absent [88]. Furthermore, a 1-h exposure to $900 \mathrm{ppm}$ gasoline vapor caused slight dizziness and irritation of the eyes, nose, and throat. At 10000 ppm, nose and throat irritation developed within $2 \mathrm{~min}$, and dizziness within $4 \mathrm{~min}$, while signs of intoxication developed in 4-10 min in exposed humans.

In a similar manner, numerous behavioral and biochemical effects have been reported in studies of animals after short- and/or long-term exposure to gasoline vapor. Kinawy [89] reported significant fluctuation in levels of monoamine neurotransmitters (dopamine, norepinephrine, and serotonin) and other biochemical parameters (sodium-potassium adenosine triphosphatase $\left(\mathrm{Na}^{+} /\right.$ $\mathrm{K}^{+}$/ATPase), superoxide dismutase, acetylcholinesterase (AChE), protein (Pr), GSH, lipid peroxidase) in different brain areas of animals exposed to gasoline vapor.

Several reports support that induction of oxidative stress by metabolites from gasoline constituents underlies the pathogenesis of its neurotoxic effects. In many of these studies, biochemical markers of oxidative stress were found to increase, while antioxidant enzymes decreased significantly. Animals exposed to gasoline vapor had significantly elevated levels of lipid peroxides and a decrease in superoxide dismutase activity in brain and liver [89,90]. The underlying neuropathology associated with oxidative stress may include non-specific cell membrane interactions, leading to impaired membrane $\mathrm{Na}^{+} / \mathrm{K}^{+} /$ATPase activity [91] and modulation of multiple neurotransmitter systems (Figure 5). Exposure to toluene was found to decrease N-methyl-D-aspartate currents and increase gamma-aminobutyric acid (GABA) currents as well as glycine receptors [92].

\section{Nephrotoxicity}

Although previously debated [93], several recent studies [94] have shown that frequent and heavy exposure to 


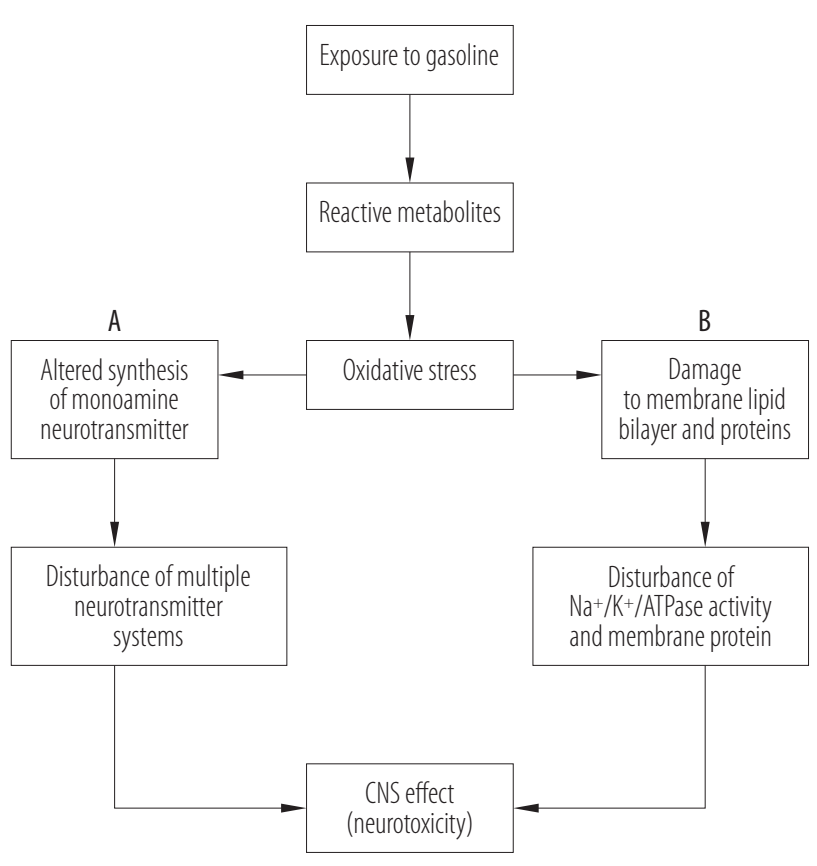

$\mathrm{Na}^{+} / \mathrm{K}^{+} /$ATPase - sodium-potassium adenosine triphosphatase; CNS - central nervous system.

Reactive metabolites generated by the oxidative metabolism of gasoline compounds generate ROS causing oxidative stress. Possible pathways:

A - alternatively, oxidative stress may cause alterations in multiple neurotransmitter systems and hence neurotoxicity;

$\mathrm{B}$ - oxidative stress may induce non-specific membrane interactions leading to damage to membrane lipid bilayer and proteins, subsequent disturbance of transmembrane enzyme activities, and hence neurotoxicity.

Fig. 5. Possible pathways of gasoline-induced neurotoxicity

gasoline constituents is associated with increased risk of renal function impairment, due to their potential to either initiate kidney injury or worsen extant impaired renal function, or both $[95,96]$.

In many cases, the glomerular cells and tubular cells of the kidney are the most vulnerable site for injury [97]. Characteristically, these sites are more sensitive to vasoactive compounds; possess efficient reabsorption and secretion processes, many transporters, large membrane surface areas, high intracellular concentrating potential, and baseline medullary hypoxia, increasing the risk of damage by toxicants and solvents.
Studies of both humans and experimental animals indicate that exposure to gasoline compounds is associated with a significantly higher risk of abnormal values of nephrotoxicity markers, including derangement in serum electrolyte (potassium $\left(\mathrm{K}^{+}\right)$, sodium $\left(\mathrm{Na}^{+}\right)$, calcium $\left(\mathrm{Ca}^{2+}\right)$, chloride $\left(\mathrm{Cl}^{-}\right)$, and bicarbonate $\left.\left(\mathrm{HCO}_{3}^{-}\right)\right)$balance $[98$ 103]. Impaired excretion of metabolic waste products, e.g., creatinine, urea, blood urea nitrogen (BUN), and uric acid [94,104,105], and altered acid-base homeostasis [102]. Studies among healthy workers exposed to hydrocarbons have shown a higher incidence of proteinuria, oliguria, albuminuria, hematuria, and leucocyturia than controls [50,106109]. Furthermore, an increased incidence of raised blood pressure (BP) [103] and anaemia [6] has also been reported. In several human studies, prolonged exposure to hydrocarbons has also been found to be associated with a variety of severe glomerular lesions, including mild to severe glomerular nephritis (GN) and Goodpasture's syndrome [110-115].

Evidently, hydrocarbon exposure may indeed induce GN and worsen its course, and hence renal function, in many patients [116]. Additionally, acute tubular injury, including tubular necrosis, and interstitial oedema with associated histopathological changes, has been reported in humans [115]. In a case-control study, Ishola et al. [116] showed a direct relationship between exposure to hydrocarbons and the incidence of GN in their patients. There was a significantly higher number of exposed individuals in the GN group than in the control group [116]. These findings were consistent with a previous study by Bell et al. [117], who recorded a dose-response relationship between exposure to hydrocarbons and GN.

A collaborative animal experimental study also demonstrated a wide range of lesions in the nephrons of animals exposed to hydrocarbons compared to the controls. Most of these lesions were similar to those observed in humans and included immunoglobulin A (IgA) nephritis [91], mesengial nephropathy [118], crescentic nephropathy [119], focal 
segmented proliferative nephropathy [120], glomerular sclerosis, minimal change nephropathy [121], and focal segmented nephropathy. Moreover, the analysis of 26 experimental studies in animals by Ravnskov [96] showed that animals exposed to 13 different hydrocarbons demonstrated glomerular changes reminiscent of human GN.

Several other studies $[30,122,123]$ have suggested an association between renal cancer and exposure to gasoline and gasoline constituents.

Nevertheless, a few other studies have found no association between exposure to hydrocarbons and renal function impairment, probably due to the effects of several covariates, including genetic susceptibility and sex differences [98], differences in the types and levels of hydrocarbon exposure, and the "healthy worker" effect, which may depend on the crude oil origin, differences in the processing technique and blends used, season-to-season variation, and the additives required to meet the specified standard of performance [124].

The mechanism underlying gasoline-induced renal function impairment is based on the high lipophilicity of gasoline and induction of oxidative stress. Induction of oxidative stress by gasoline oxidative metabolites has been reported to cause disruption of the immune system, including induction of autoimmunity, effects on T-cell function, suppression of immunofunction, increased post-glomerular resistance, and decreased glomerular filtration rate (GFR). Furthermore, induction of physiochemical damage to the glomerular and tubules, including damage to the membrane lipid bilayer and proteins, due to the high lipophilicity of gasoline, have been reported by Ravnskov [95]. Such damage may compromise the functional integrity of the membrane, with a resultant derangement in $\mathrm{Na}^{+} / \mathrm{K}^{+} /$ATPase activity and membrane proteins. This may lead to a cascade of events leading to renal function impairment (Figure 6).

\section{Hepatotoxicity}

Many human and animal studies [103,125-130] have shown that prolonged exposure to gasoline compounds

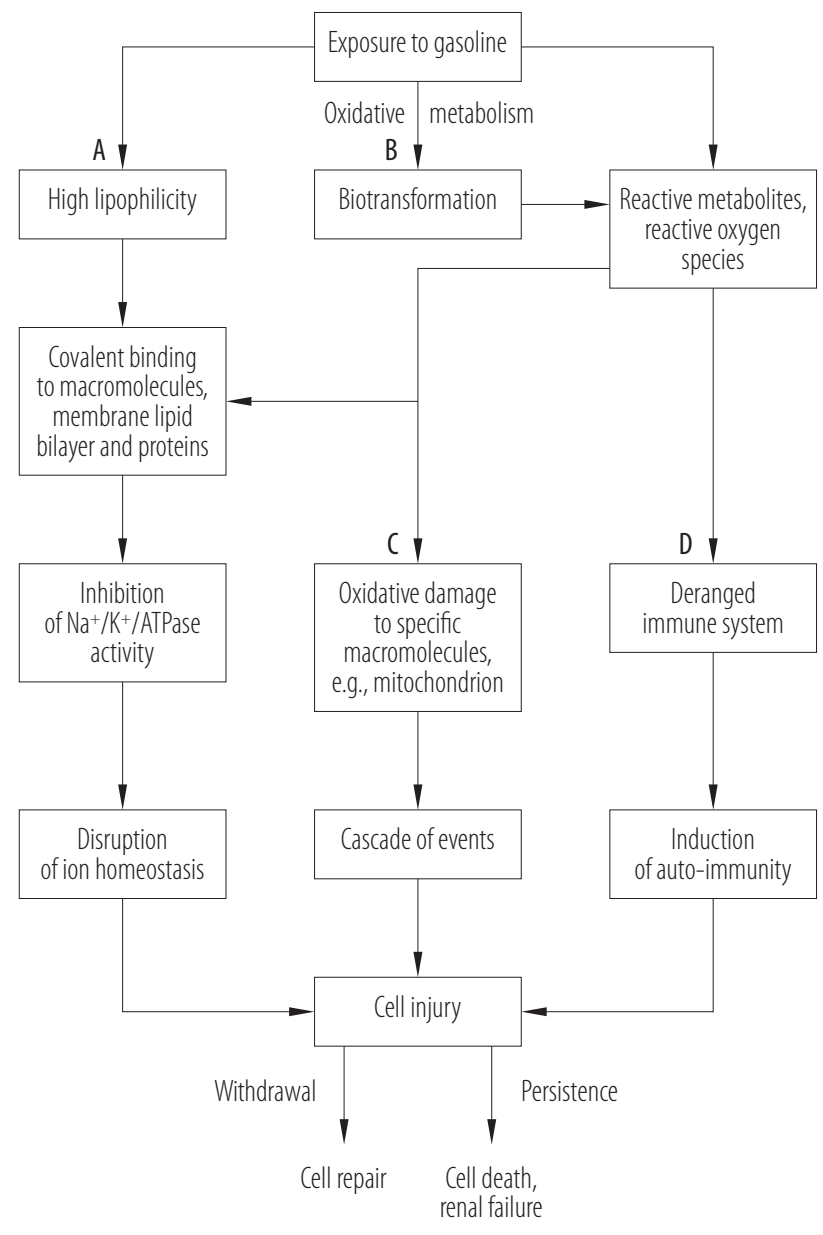

$\mathrm{Na}^{+} / \mathrm{K}^{+} /$ATPase - sodium-potassium adenosine triphosphatase.

Pathways:

A - gasoline (parent nephrotoxicant) may bind to the membrane lipid bilayer and proteins due to its high lipophilicity, leading to damage to the membrane bilayer and proteins, which causes inhibition of $\mathrm{Na}^{+} / \mathrm{K}^{+} /$ATPase activity, which in turn leads to disruption of ion homeostasis and cell injury;

$\mathrm{B}$ - alternatively, gasoline may undergo biotransformation to reactive intermediates (e.g., 1,2,3-benzenetriol and benzequinone) that bind covalently to macromolecules and in turn alter their activity (e.g., inhibition of $\mathrm{Na}^{+} / \mathrm{K}^{+} /$ATPase), resulting in cell injury; $\mathrm{C}$ - additionally, gasoline may increase in the renal cells directly after being biotransformed into reactive intermediates through redox cycling. The resultant increase in ROS may cause oxidative damage and cell injury;

D - finally, the generated ROS may cause disruption of the immune system, leading to immune perturbation, and a resultant induction of autoimmunity. This may cause cell injury. In either case, persistent exposure may lead to cell death and renal failure.

Fig. 6. Pathways underlying gasoline-induced nephrotoxicity 
(BTEX compounds) may represent a significant risk factor for a wide spectrum of liver disorders, including subclinical hepatitis, necrotic inflammatory hepatitis, cholestatic liver disorders, cirrhosis, and liver cell carcinoma, and may constitute a potential health hazard to humanity [105]. This idea is supported by several studies showing a significant correlation between exposure to gasoline or gasoline constituents, and disturbances in serum levels of liver function indices, as well as extensive histopathological changes in the animal models of exposure.

In fact, listed among the commonly affected indices are significant increases in serum levels of aspartate aminotransferase (AST), alanine aminotransferase (ALT), alkaline phosphatase (ALP), serum bilirubin concentration, gamma-glutamyl transferase (GGT), and serum protein levels $[104,126]$.

In one animal study, the histology of liver sections of the exposed animals revealed extensive liver cell effects, including significant degeneration of cells, fatty changes in the hepatocytes (hepatosteatosis), severe cell inflammation, cirrhotic changes, hepatocyte fibrosis, and necrosis [130]. Associated increases in liver size and weight (hepatomegaly) in the exposed animals have also been reported [131]. Several mechanisms contribute to gasolineinduced hepatotoxicity, including the induction of cellular degeneration, downregulation of gene expression, and induction of oxidative stress [132]. Inhibition of CYP2E1, which was recently reported in animals exposed to gasoline vapors [103] is potentially deleterious to the liver.

However, induction of oxidative stress appears to play a central role in the initiation and progression of gasolineinduced hepatotoxicity. The metabolism of gasoline and its compounds is known to generate reactive metabolites (1,2,4-benzenetriol, benzequinone), which interact with the membrane lipids of hepatocytes to produce lipid peroxide (lipid peroxidation) and ROS, including hydroxyl and superoxide radicals. Reactive oxygen species and lipid peroxidation lead to damage of the biomembrane and hepatocytes, causing leakage of the cellular components (Figure 7) [133]. This idea is supported by decreased serum antioxidant enzymes activities, including superoxide dismutase (SOD), catalase (CAT), and glutathione peroxidase (GPx), and increased levels of oxidative stress markers (lipid peroxidase, malondialdehyde (MDA)) in gasoline workers [134,135].

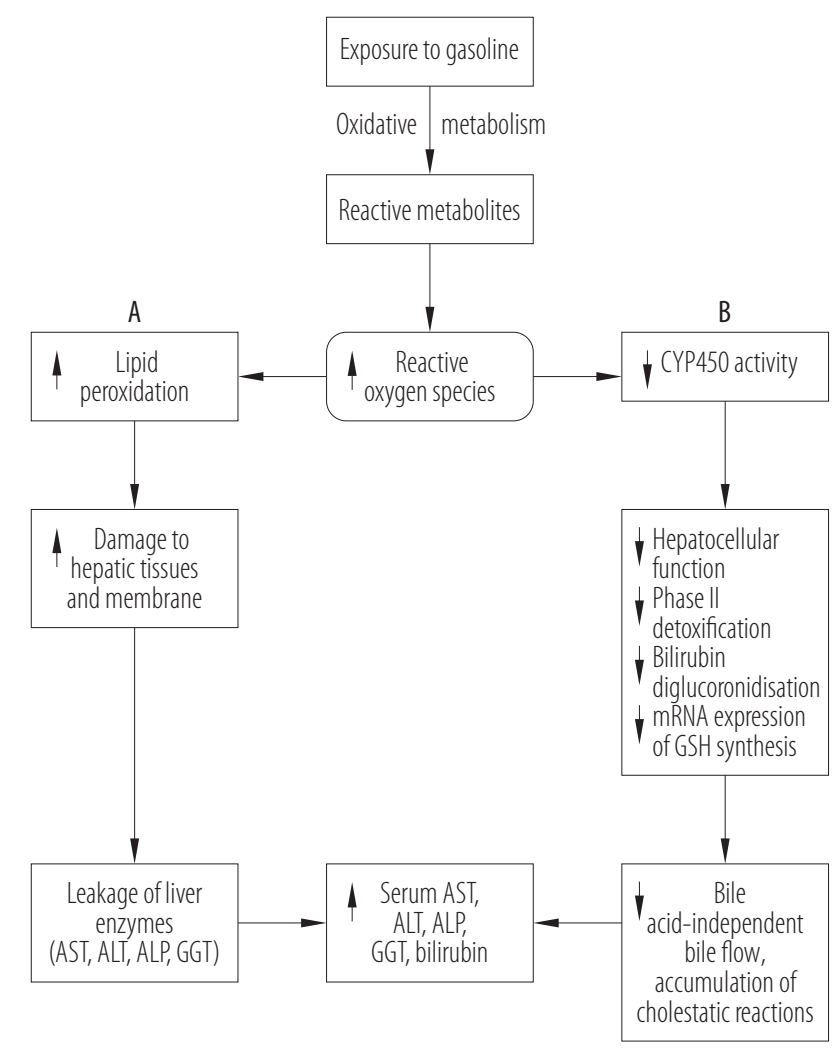

CYP450 - cytochrome P450; mRNA - messenger ribonucleic acid; GSH - glutathione; AST - aspartate aminotransferase; ALT - alanine aminotransferase; ALP - alkaline phosphatase; GGT gamma-glutamyl transferase.

Mechanisms:

A - generation of ROS leads to lipid peroxidation and damage to the hepatic membrane and tissues; leakage of hepatic enzymes and an increase in their serum levels ensues;

B - additionally, impairment of CYP450 enzyme activity may trigger a cascade of biochemical processes, leading to decreased bile acid-independent bile flow and accumulation of cholestatic reactions, which subsequently increase serum levels of bilirubin and ALP.

Fig. 7. Mechanisms of gasoline-induced hepatotoxicity 
Induction of hepatic CYP450 by gasoline hydrocarbons has also been postulated. One study reported a decrease in CYP2E1 by $34 \%$ in female mice exposed to $50 \mathrm{mg} / \mathrm{kg}$ of benzene for 3 weeks [136]. Such effects on CYP450 have been reported to induce several hepatocellular disorders, including cholestasis, hepatitis, and cirrhosis [137-140].

In studies by George et al. [141] and Tanaka et al. [142], inhibition of CYTP450 caused significant cholestatic liver disorders that led to increased serum bilirubin, total bile acid, and alkaline phosphatase levels, which was similar to the changes previously observed in gasoline station attendants following prolonged exposure to gasoline vapors.

\section{Cardiotoxicity}

Some data indicates that long-term exposure to organic solvents, including gasoline or gasoline compounds, is significantly associated with a higher prevalence of hypertension [14,143-147]. In particular, Bener et al. [144] found a statistically significantly higher prevalence of hypertension among workers exposed to gasoline vapors at different gasoline stations than among unexposed individuals. Additionally, Wiwanitkit [146] reported a significantly higher prevalence of hypertension in workers with a higher exposure to benzene $(100 \%)$ than in the less exposed groups (49\%). Likewise, a study by Kotseva and Popov [145] found a higher risk of hypertension among workers occupationally exposed to a high level of xylene and benzene.

A collaborative study by Mørck et al. [143] recorded a significant increase in the systolic BP of humans occupationally exposed to toluene. Poklis [14] and Litovitz [148] reported increased cardiac sensitization to circulating catecholamines, leading to severe arrhythmias and death, in humans exposed to high concentrations of gasoline. Kotseva and Popov [145] found an increased prevalence of hypertension and pathological changes in electrocardiograms (ECG) of workers exposed to benzene in a petro-chemical factory.

Similarly, Uboh et al. [131] found disturbances in serum electrolytes levels (hyperkalaemia, hyponatraemia) and a significant increase in the atherogenic index of plasma (AIP) in animals exposed to gasoline vapors. Consequently, exposure to gasoline vapors could be associated with the risk of atherosclerosis and hence cardiovascular disease. The pathophysiology of cardiovascular disease associated with gasoline exposure is unclear; however, studies suggest the role of oxidative stress in various pathogenic processes, leading to hypertension and other cardiovascular diseases (Figure 8). These include, but are not limited to, disturbances in the regulatory role of nitric oxide (NO) [146,147,149].

It is known that bioactive gasoline metabolites may induce an oxidant/antioxidant imbalance, generate the ROS, and hence increase oxidative stress. Oxidative stress inhibits nitric oxide synthesis through the inhibition of dimethyl arginine, dimethyl aminohydrase (DDAH), which is an enzyme known to degrade methyl arginine, a nitric oxide synthase (NOS) inhibitor. When DDAH is inhibited, methyl arginine accumulates, causing inhibition of NOS, and leading to vasoconstriction, increased peripheral resistance, and thereby an increase in BP [150]. Additionally, evidence suggests that oxidative stress could also result in the development of atherosclerotic cardiovascular disease [151,152]. This idea is supported by the findings of atherogenic dyslipidaemia and an increased AIP in humans and animals exposed to gasoline fumes [131].

Some gasoline constituents have also been found to disrupt various myocardial enzyme activities, leading to impaired intracellular conduction and myocardial electrolyte disturbances. Disturbances in the activity of $\mathrm{Na}^{+} / \mathrm{K}^{+} /$ ATPase, leading to changes in intracellular $\mathrm{Na}^{+}, \mathrm{K}^{+}, \mathrm{Mg}^{2+}$, and $\mathrm{Ca}^{2+}$ levels, as well as changes in the ECG, have been reported in humans and animals exposed to gasoline vapors [145]. 


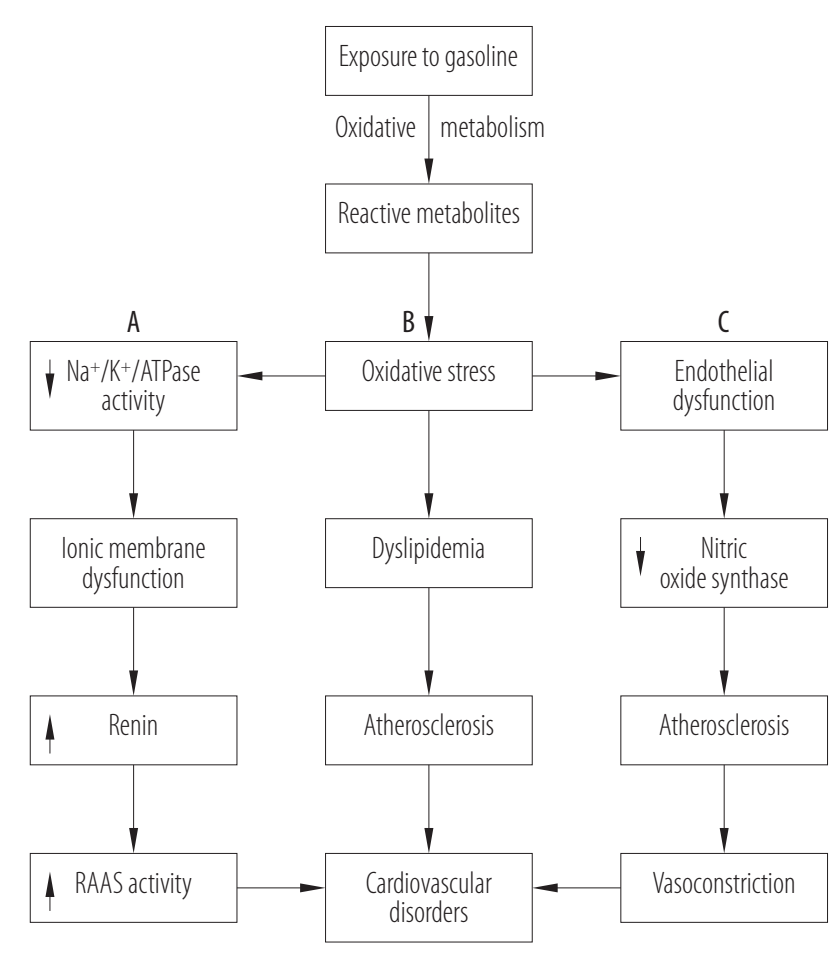

$\mathrm{Na}^{+} / \mathrm{K}^{+} /$ATPase - sodium-potassium adenosine triphosphatase; RAAS - renin angiotensin aldosterone system.

Pathways:

A - alteration of transmembrane enzyme activities may result in ionic membrane dysfunction, increased RAAS activity, and associated cardiovascular pathologies, including hypertension;

B - oxidative stress may cause the development of atherosclerotic cardiovascular disease;

$\mathrm{C}$ - oxidative stress induced by the reactive metabolites from gasoline metabolism may impair synthesis of nitric oxide leading to atherosclerosis and vasoconstriction and cardiovascular pathologies including hypertension.

Fig. 8. Pathways underlying gasoline-induced cardiotoxicity

\section{Genotoxicity}

Available data suggests that gasoline station workers are exposed to several potential genotoxins in gasoline vapors [84,152,153], including benzene, xylene, toluene, and other chemicals [154]. However, benzene is considered the most hazardous, due to its genotoxic and carcinogenic effects [153,154].

Many studies have shown that exposure to these compounds has the potential to cause chromosomal/genetic aberrations, including strand breakage, deletion of sister chromatid exchange (SCE), nondisjunction, mitotic interference, or misaggregation of chromatin [154-156]. Other observations include significant increases in mean comet tail length and the frequency of micronuclei in peripheral blood lymphocytes (PBL). In particular, these genotoxic biomarkers have been found at higher levels in gasoline station workers than in control groups [155,157]. Moreover, Tunsaringkarn et al. [83] and Moro et al. [158] have reported a significant correlation between blood and air levels of gasoline constituents and the levels of genotoxic biomarkers. Their study findings were consistent with those of several other previous reports [159].

Indeed, gasoline station workers are at risk of significant cytogenetic damage, as demonstrated by other investigations [160]. Nevertheless, gasoline-induced genotoxicity has been somewhat inconsistent and may depend on the demographic characteristics of the study participants, including age, gender, race, dietary habits, physical activity status, alcohol intake, and smoking habits. Other factors include the duration of exposure, exposure volume of gasoline per unit of time, past medical history, family history, and simultaneous exposure to multiple genotoxic agents. For instance, many studies have observed an increase in biomarkers of genotoxicity within a few years after exposure to gasoline and a subsequent decrease over time [152,153], but other studies found no significant relationship between genotoxic effects and the duration of exposure [161].

Bukvic et al. [162], found no relationship between the frequencies of SCE and the duration of employment in the gasoline industry. The explanation for the inverse relationship between the blood levels of genotoxic biomarkers and the duration of exposure to gasoline varies. According to Yadav and Seth [152], a higher degree of damage to peripheral lymphocytes could cause depletion of aberrant cells on prolonged exposure; the health worker effect is another plausible explanation [163]. 


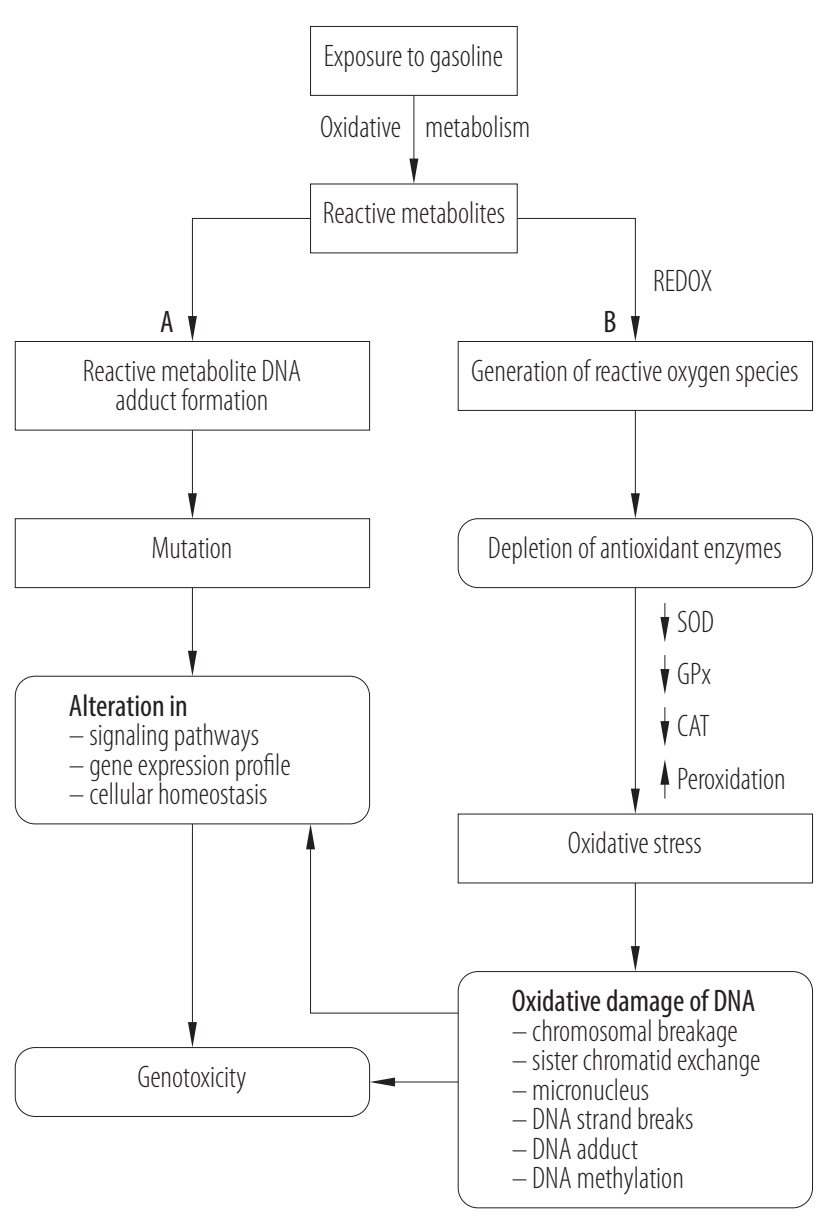

REDOX - reduction-oxidation.

Other abbreviations as in Figure 3.

Mechanisms:

A - gasoline metabolites form adducts with DNA, leading to mutation, and alteration in signaling pathways, gene expression profiles, and cellular homeostasis, as well as genotoxic effects; $\mathrm{B}$ - generation of reactive metabolites from gasoline metabolism leads to depletion of antioxidant enzymes, oxidative damage to DNA, and ultimately to genotoxicity.

Fig. 9. Mechanisms of gasoline-induced genotoxicity

Similarly, while age and sex were not positively associated with chromosomal damage in some studies, others found the converse [161,164]. According to Rekhadevi et al. [165], gasoline-induced genotoxicity may be confounded by the life-style habits of the exposed gasoline service station attendants, including smoking habits, diet, and alcohol intake. Moreover, the confounding effect of the concentration of the implicated gasoline compound has been highlighted. For instance, while toluene and xylene causes significant cell growth inhibition, exposure to benzene at the same concentration is not associated with genotoxic endpoints [166].

A number of pathophysiological mechanisms have been postulated to underlie the genotoxic effects of gasoline and gasoline constituents, including the generation of ROS, following their breakdown to produce reactive metabolites, and subsequent interaction of ROS with DNA to induce stand breaks [153,167]. It has been postulated that the reactive metabolites resulting from gasoline bioactivation covalently bind to cellular proteins and DNA, leading to the formation of DNA adducts, and causing toxicity via multiple mechanisms, such as direct cytotoxicity, oncogene activation, chromosomal aberration, and downregulation of the host tumor control mechanisms (Figure 9) [168,169].

\section{Immunotoxicity}

It is long-known that occupational exposure to certain chemicals may induce severe immune disorders in humans [170]; nevertheless, few studies have examined the immunotoxic effects of gasoline on exposed gasoline station workers or workers in other petro-chemical industries. This is probably due to the complexity of the immune response and the difficulty of studying the system in vivo. Findings from animal studies are clearer and are predominant in the literature. In this review, few human studies on the changes in the immune response pattern in gasoline station workers were found.

A cross-sectional study conducted by Akinosun et al. [171] on 29 gasoline station workers and 22 age- and sex-matched controls found no significant differences in the levels of immunoglobulin (Ig) A and $\operatorname{IgG}$ between gasoline station workers and controls, while IgM levels were significantly increased in petrol attendants as compared with controls. A recent animal study by White et al. [172] concluded 
that gasoline, either on its own or mixed with certain nonimmunotoxic additives (e.g., t-amyl methyl ether (TAME), and t-butyl alcohol (TBA)) did not adversely affect the humoral immune response of the test animals; however, when mixed with some immunotoxic agents, such as ethanol (EtOH) [173,174], ethyl t-butyl ether (ETBE), and diisopropyl ether (DIPE), suppressed humoral responses.

Gasoline immunotoxicity may indeed be influenced by additive immunotoxins, particularly when present at a high concentration or upon prolonged exposure. This concept is supported in a study by Uzma et al. [169] who observed significant decreases in Ig levels, cluster of differentiation $4(\mathrm{CD} 4) \mathrm{T}$ cells and the $\mathrm{CD} 4^{+} / \mathrm{CD}^{+}$ratio among gasoline station workers exposed to benzene, which is known for its immunotoxic effects [175-177], including suppression of the components and function of the immune system, such as suppression of Ig production and activities of B- and T-lymphocytes in both acute and chronic epidemiological studies [140,178,179]. Increased markers of oxidative stress (ROS and serum MDA), as well as decreased antioxidant enzymes (GSH and total superoxide dismutase (T-SOD)), have been observed in exposed individuals as compared with controls, suggesting the role of oxidative stress in the pathogenesis of the immunotoxicity. These findings are consistent with previous studies showing an association between oxidative stress and impaired cell-mediated and humoral immunity [180].

\section{Effect on special senses}

\section{Ototoxicity}

There is significant empirical data suggesting that high levels of acute exposure or low levels of chronic exposure to gasoline or gasoline constituents is associated with a higher prevalence of hearing impairment or loss [181,182]. Tochetto et al. [183] reported a greater and time-dependent absence of acoustic reflexes and an exacerbated acoustic reflex, which is evidence of cochlear and central auditory pathway effects, in gasoline station attendants in the city of
Santa Maria. In a similar study, Quevedo et al. [184] found that exposure to fuel for a minimum of 3 years may cause changes in the central auditory system, even in individuals with normal auditory thresholds, with a characteristic increase in absolute latencies and interaural differences in the wave pattern of the brain-stem auditory potential. Thus, service attendants at gasoline stations are exposed to the risk of impaired hearing or hearing loss.

\section{Ocular effects}

Emerging evidence suggests that occupational exposure to organic solvents may be associated with impairment of visual function in many respects, and in particular color vision, including losses of blue yellow color, and secondary red green color dyschromatopsia [185-187].

In a psychophysical test for evaluating visual function in 29 gas station workers, Lacerda et al. [188] found lower spatial contrast sensitivities, higher error values in frequency modulation 100 (FM100), and a wider color discrimination ellipse area in exposed workers as compared with controls.

A cross-sectional study by Costa et al. [189] assessing the visual outcome of chronic exposure to a mixture of organic solvents among 25 gas station workers reported significantly higher color discrimination thresholds, along the protein, deutan, and tritan confusion axis, and higher ellipse and ellipticity areas in the exposed workers as compared with control groups. Sirdah et al. [190] also found significantly more complaints of eye itches, redness, and pain among workers at liquefied petroleum gas stations in the Gaza governorate. Therefore, gasoline station workers may be exposed to a higher risk of visual impairment.

\section{Dermatologic effects}

Growing evidence suggests that prolonged or repeated exposure to gasoline may be associated with various forms of skin lesions or manifestations. Sirdah et al. [190] reported a higher prevalence of skin redness, rashes, and itching 
in exposed workers than in the control group. In a study of 52 gasoline exposed workers and 52 control subjects, Jia et al. [191] found a higher prevalence of hyperkeratosis, dryness, onychosis, and dermatitis in exposed workers than in the control group. Significantly lower levels of stratum corneum lipid ceramide, fatty acid, and cholesterol levels were also noted among the exposed workers, while symptoms, such as fissures and onychorrhexis, were more common among the exposed workers than in the control group.

\section{Carcinogenic effects}

Several epidemiological studies suggest that gasoline exposure may be a cause of some human cancers. Nevertheless, the pattern that emerges from these studies is not fully consistent. While in some instances, trends and geographic patterns of gasoline exposure and cancer mortality is moderately supportive of such a relationship, most other ecological correlations do not support this. However, previous studies have shown a higher prevalence of certain cancers, including renal cell carcinoma [123,192], acute myeloid leukemia [193], and nasal cancer in gasoline service station attendants than in the control groups.

\section{CONCLUSIONS}

Recent advances in toxicity testing have indeed improved the quality and quantity of data regarding the multi-system toxic effects of gasoline on exposed humans. Data gathered from this review provide insight into the mechanism of adverse effects due to gasoline exposure and related to oxidative stress.

Available evidence supports the bio-activation, generation of reactive metabolites, and induction of oxidative stress as critical steps in the pathophysiology of gasolineinduced multi-systemic pathologies. However, the modulatory roles of individuals' susceptibility factors and variations in geographic patterns in gasoline exposure have yielded inconsistent research results across the globe.
The evolving understanding of the molecular basis for the multi-systemic pathologies induced by gasoline could facilitate preventative measures and the development of more effective therapeutic strategies against gasoline induce negative effects. Furthermore, the studies reviewed here indicate that the research literature on this topic is still incomplete; these gaps should be addressed in future studies. In particular, exposure misclassification should be minimized. Detailed evaluation of gasoline exposure indices (exposure dose and duration, frequency of peak exposure, and exact composition of gasoline compounds causing effects) is recommended. Additionally, the effect of individual susceptibility factors on the toxicokinetic profile of gasoline constituents is highlighted here. In all, the impact of gasoline on human health poses serious health challenges to humanity globally, and particularly in developing countries.

\section{ACKNOWLEDGMENTS}

The authors are grateful to the management of Sifon Clinic Ltd., Uyo, Nigeria, for providing technical support and valuable suggestions.

\section{REFERENCES}

1. Rosenstock L, Culen M, Fingerhut M. Disease control priorities in developing countries. Occup Health. 1990;1:1127-45.

2. International Labor Organization. GB.300/LILS/10: Project on economic dynamics of international labour standards [Internet]. Geneva: International Labour Office; 2007. Available from: http://www.ilo.org/gb/WCMS_084831/lang--en/index.htm.

3. Cezar-Vaz MR, Rocha LP, Bonow CA, Santos da Silva MR, Vaz JC, Cardoso LS. Risk perception and occupational accident: A study of gas station workers in Southern Brazil. Int J Environ Res Public Health. 2012;9:2362-77, https://doi. org/10.3390/ijerph9072362.

4. Azari MR, Konjin ZN, Zayeri F, Salehpour S, Seyedi MD. Occupational exposure of petroleum depot workers to BTEX compound. Int J Occup Environ Med. 2012;3:39-44. 
5. Adeniyi BO. Pulmonary function and symptoms among petrol pump attendants in Nigeria. Int J Biol Med Res. 2014;5:3780-4.

6. Ajugwo AO, Adias TC, Aghatise K, Fadairo JK, Nyenke CU. Reduced haematological indices in auto-mechanics and fuel attendants in Elele Nigeria. Am J Med Biol Res. 2014;2:1-4, https://doi.org/10.12691/ajmbr-2-1-1.

7. Ekpenyong CE, Davies K, Daniel N. Effect of gasoline inhalation on menstrual characteristics and the hormonal profile of female petrol pump workers. J Environ Protect. 2013;4:65-73, https://doi.org/10.4236/jep.2013. 48A1009.

8. Swick D, Jaques A, Waker JC, Estreicher H. Gasoline toxicology: Overview of regulatory and product stewardship programs. Regul Toxicol Pharmacol. 2014;70:3-12, https://doi. org/10.1016/j.yrtph.2014.06.016.

9. McDonald JD, Reed MD, Campen MJ, Barrett EG, Seagrave JC, Mauderly JL. Health effects of inhaled gasoline engine emissions. Inhal Toxicol. 2007;19:107-16, https://doi. org/10.1080/08958370701495279.

10. Costantini MG. Health effects of oxygenated fuels. Environ Health Perspect. 1993;101:51-60.

11. Mutti A, Coccini T, Alinovi R, Toubeau G, Broechaert F, Bergamaschi E, et al. Exposure to hydrocarbon and renal disease: An experimental animal model. Ren Fail. 1999;21: 369-85, https://doi.org/10.3109/08860229909085101.

12. Wang CC, Irons GV Jr. Acute gasoline intoxication. Arch Environ Health. 1961;2:714-6, https://doi.org/10.1080/00039 896.1961.10662929.

13. Boeck RL, Postl B, Coodin FJ. Gasoline sniffing and tetraethyl lead poisoning in children. Pediatrics. 1977;60:140-5.

14. Poklis A. Death resulting from gasoline "sniffing": A case report. J Forensic Sci Soc. 1977;16:43-46, https://doi. org/10.1016/S0015-7368(76)71024-7.

15. Franceschetti P, Soleo L, Lovreglio P, Ballini A, Doria D, Carrieri M, et al. Workers exposure to low levels of benzene biomarkers of exposure and effect. Pharmacologyonline. 2005;3:54-65.
16. Sahb AAA. Hematological assessment of gasoline exposure among petrol filling workers in Baghdad. J Fac Med Baghdad. 2011;53:396-400.

17. Tunsaringkarn T, Soogarun S, Palasuwa A. Occupational exposure to benzene and changes in hematological parameters and urinary trans, trans-muconic acid. Int J Occup Environ. 2013;4:45-9.

18. Yoon B, Hirabayashi Y, Kawasaki Y, Kodama Y, Keneko T, Kim AY, et al. Mechanism of action of benzene toxicity: Cell cycle suppression in hemopoietic progenitor cell (CFU-GM). Exp Hematol. 2001;29:278-85.

19. Qu Q, Shore R, Li G, Jin X, Chen LC, Cohen B, et al. Hematological changes among Chinese worker with a broad range of benzene exposures. Am J Ind Med. 2002;42:275-85.

20. Okoro AM, Ani EJ, Ibu JO, Akpogomeh BA. Effect of petroleum products inhalation on some haematological indices of fuel attendants in Calaber Metropolis, Nigeria. Nig J Physiol Sci. 2006;21:71-5.

21. Udonwa NE, Uko EK, Ikpeme BM, Ibanga IA, Okon BO. Exposure of petrol station attendants and auto mechanics to premium motor spirit fumes in Calabar, Nigeria. J Environ Public Health. 2009;2009:281876, https://doi.org/10. 1155/2009/281876.

22. Glass DC, Gray CN, Jolley DJ, Gibbons C, Sim MR, Fritschi $\mathrm{L}$, et al. Leukemia risk associated with low-level of benzene exposure. Epidemiology. 2003;14:569-77, https://doi. org/10.1097/01.ede.0000082001.05563.e0.

23. Lan Q, Zhang L, Li G, Vermeulen R, Weinberg RS, Dosemeci $\mathrm{M}$, et al. Hematotoxicity in workers exposed to low levels of benzene. Science. 2004;306:1774-6, https://doi.org/ 10.1126/science.1102443.

24. Kirkeleit J, Riise T, Gjertsen BT, Moen BE, Braveit M, Bruserua Q. Effect of benzene in human hematopoiesis. Open Hematol J. 2008;2:87-102.

25. Aleemuddin M, Baba MG, Manjunath ML, Quadri SS. Effect of chronic inhalation of petroleum products on hematological parameters. Int J Curr Res Aca Rev. 2015;3(4): 196-201. 
26. Akintonwa A, Ojo BA, Emeka P, Coker HAB, Sefola O. Effect of chronic exposure to petroleum products on some hematological and biochemical parameters. Nig Q J Hosp Med. 2005;15(2):77-82.

27. Ikeda M, Otsuji H, Imamura T. In vivo suppression of benzene and styrene oxidation by co-administered toluene and effects of phenobarbital. Xenobiotica. 1972;2:101-6, https:// doi.org/10.3109/00498257209111041.

28. Tunek A, Olofsson T, Berlin M. Toxic effects of benzene and benzene metabolites on granulopoietic stem cells and bone marrow cellularity in mice. Toxicol Appl Pharmacol. 1981;59: 149-56, https://doi.org/10.1016/0041-008X(81)90462-2.

29. Andrews LS, Lee EW, Witmer CM, Kocsis JJ, Synder R. Effect of toluene on the metabolism disposition and hemopoietic toxicity of H-benzene. Biochem Pharmacol. 1997;26:293-300.

30. Schnatter AR, Kerzic PJ, Zhou Y, Chen M, Nicolich MJ, Lavelle K, et al. Peripheral blood effects in benzene-exposed workers. Chem Biol Interact. 2010;184:174-81.

31. Sato A, Nakajima T. Pharmacokinetics of organic solvent vapours in relation to their toxicity. Scand J Work Environ Health. 1987;13:81-93, https://doi.org/10.5271/sjweh.2075.

32. Yardley-Jones A, Anderson D, Parke DV. The toxicology of benzene and metabolism and molecular pathology in human risk assessment. Br J Ind Med. 1991;48:437-44.

33. Carletti R, Romano D. Assessing health risk from benzene pollution in an urban area. Environ Monit Assess. 2002;80:135-48, https://doi.org/10.1023/A:1020691506835.

34. Ekpenyong CE, Daniel NE, Antai AB. Bioactive natural constituents from lemongrass tea and erythropoiesis boosting effects: Potential use in prevention and treatment of anemia. J Med Food. 2015;18:118-27, https://doi.org/10.1089/ jmf.2013.0184.

35. Rothman N, Dosemeci M, Bechtold WE, Marti GE, Wang YZ, Linet M, et al. Hematotoxicity among Chinese workers heavily exposed to benzene. Am J Ind Med. 1996;29:236-46.

36. Lemaster GK, Olsen DM, Yiin JH, Lockey JE, Shukla R, Selevan SG, et al. Male reproductive effects of solvent and fuel exposure during aircraft maintenance. Reprod Toxicol. 1999;13:155-66.

37. Xu X, Cho SI, Sammel M, You L, Cui S, Huang Y, et al. Association of petrochemical exposure with spontaneous abortion. Occup Environ Med. 1998;55:321-36.

38. Chen D, Cho S, Chen C, Wang X, Damokosh AI, Ryan L, et al. Exposure to benzene, occupational stress, and reduced birth weight. Occup Environ Med. 2000;57:661-7.

39. Slama R, Thiebaugearges O, Goua V, Aussel L, Sacco P, Bohet A, et al. EDEN mother-child cohort study group. Maternal personal exposure to air born benzene and intrauterine growth. Environ Health Perspect. 2009;177:1313-21.

40. Hatch MC, Warburton D, Santella RM. Polycyclic aromatic hydrocarbon-DNA adducts in spontaneously aborted fetal tissues. Carcinogenesis. 1990;11:1673-5, https://doi. org/10.1093/carcin/11.9.1673.

41. Ugwoke CC, Nwobodo ED, Unekwe P, Odike M, Chukwuma ST, Amilo G. The reproductive dysfunction effects of gasoline inhalation in albino rats. Nig J Physiol Sci. 2005;20:54-7.

42. Maronpot RR. Ovarian toxicity and carcinogenicity in 8 recent National Toxicity Program studies. Environ Health Perspect. 1987;73:125-30, https://doi.org/10.1289/ehp.8773125.

43. Sirotkin AV, Kadasi A, Balazi A, Bakova Z, Harrath AH, Makarevich AV, et al. Influence of petrochemical industry environmental contaminants on animal ovarian cells. J Microbiol Biotechnol Food Sci. 2012;2:517-25.

44. Hannigan JH, Bowen ES. Reproductive toxicology and teratology and abused toluene. Syst Biol Reprod Med. 2010;56: 184-200, https://doi.org/10.3109/19396360903377195.

45. Xiao G, Pan C, Cai Y, Lin H, Fu Z. Effect of benzene, toluene, xylene on semen quality of exposed workers. China Med J. 1999;112:709-12.

46. Rao NR, Snyder R. Oxidative modifications produces in HL-60 cells on exposure to benzene metabolites. J Appl Toxicol. 1995;15:403-9, https://doi.org/10.1002/jat.2550150511.

47. Laskin JD, Rao NR, Punjabi CJ, Laskin DL, Synder R. Distinct actions of benzene and its metabolites on nitric oxide production by bone marrow leukocytes. J Leukoc Biol. 1995;57:422-6. 
48. Burmistrov SO, Arutyunyan AV, Stepanov MG, Oparina TI, Prokopenko VM. Effect of chronic inhalation of toluene and dioxane on activity of free radical processes in rat ovaries and brain. Bull Exp Biol Med. 2001;132:832-6, https://doi. org/10.1023/A:1013106315140.

49. Kim DH, Lee H, Lee CK, Kang DS, Kin JH, Lee JT, et al. Effects of toluene, xylene and trichloroethylene on the regulation of RnRH reception and Pit-1 gene expression in male rat hypothalamus and pituitary. Korean J Occup Environ Med. 1998;10:267-81.

50. Ahmed FA. Toxicology and human health effects following exposure to oxygenated gasoline. Toxicol Lett. 2001;123:89113, https://doi.org/10.1016/S0378-4274(01)00375-7.

51. Singhal M, Khalia F, Singhal S, Tandon OP. Pulmonary functions in petrol pump workers: A preliminary study. Indian J Physiol Pharmacol. 2007;51:244-8.

52. Begum S, Rathna MB. Pulmonary function test in petrol filling workers in Mysore city. Pak J Physiol. 2012;8:12-4.

53. Hulke SM, Patil PM, Thakare AE, Vaidya YP. Lung function test in petrol pump worker. Natl J Physiol Pharm Pharmacol. 2012;2:71-5.

54. Sharma N, Gupta N, Gupta R. Ventilatory impairment in petrol pump workers. JK Sci. 2012;14:5-8.

55. Gouroju S. Pulmonay function test in petrol pump workers in Chittoor district. Int J Physiother Res. 2014;2:354-8.

56. Niraimathi D, Kamakshi M, John NA, Vasudevan K. Comparison of peak expiratory flow rate and forced vital capacity between petrol pump workers and automobile repair workers. Int J Biol Med Res. 2014;5:4084-8.

57. Sinha A, Patil SN. Pulmonary function tests in petrol pump workers in Karad town. Int J Biol Med Res. 2014;5:260-3.

58. Tardif R, Liu L, Raizenne M. Exhaled ethanol and acetaldehyde in human subjects exposed to low levels of ethanol. Inhal Toxicol. 2004;16:203-7.

59. Ezzat AR, Riad NH, Fares N, Hegazy HG, Alrefadi MA. Gasoline inhalation induces perturbation in the rat lung antioxidant defense system and tissue structure. Int J Environ Sci Eng. 2011;1:1-14.
60. Dube S, Mungal SU, Kulkarni M. Evaluation of respiratory functions in petrol pump workers at Nanded. Int J Recent Trends Sci Technol. 2013;8:149-52.

61. Anuja AV, Veeraiah V, Johnson P, Subashini AS. Evaluation and comparison of pulmonary function tests in petrol pump workers vs individuals unexposed to petrol fumed. J Clin Biomed Sci. 2014;4:276-81.

62. Chidri SV, Patil S. Assessment of pulmonary function tests in petrol workers: A cross sectional study. Indian J Basic Appl Med Res. 2014;3:507-10.

63. Parker DL, Waller K, Himrich D, Martinez A, Martin FA. Cross sectional study of pulmonary function in auto body repair workers. Am J Public Health. 1991;81:768-71.

64. Cullen MR, Redlich CA, Beckett WS, Weltmann B, Sparer J, Jackson G, et al. Feasibility study of respiratory questionnaire and peak flow recordings in Uto body shop workers exposed to isocyanate-containing spray paint: Observations and limitations. Occup Med. 1996;46: 197-204.

65. Chattopadhyay O. Pulmonary functions in automobile repair workers. Indian J Community Med. 2007;32:40-2.

66. Aprajita NKP, Panwar NK, Sharma RS. A study on the lung function test in petrol pump workers. J Clin Diagn Res. 2011;5:1046-50.

67. Ware JH, Spengler JD, Neas LM, Samet JM, Wagner GR, Coultas D. Respiratory and irritant health effects of ambient volatile organic compounds. The Kanawa county health study. Am J Epidemiol. 1993;137:1287-1301.

68. Salvi S, Blomberg A, Rudell B, Kelly F, Sandstrom T, Holgate ST, et al. Acute inflammatory response in the airways and peripheral blood after short-term exposure to diesel exhausts in healthy humans volunteers. Am J Respir Crit Care Med. 1999;159:702-9.

69. Behndig AF, Mudway IS, Brown JL, Stenfors N, Helleday R, Duggan ST, et al. Airway antioxidant and anti-inflammatory responses to diesel exhaust exposure in healthy human. Eur Respir J. 2006;27:359-65, https://doi.org/10.1183/09031936. 06.00136904 . 
70. Wooden MA, Hauser R, Liu Y, Smith TJ, Siegel PD, Lewis DM, et al. Molecular markers of acute upper airway inflammation in workers exposed to fuel-oil ash. Am J Respir Crit Care Med. 1998;158:182-7.

71. Grebic D, Jakovac H, Mrakovcic-Sutic I, Tomac J, Bulog A, Micovic V, et al. Short-term exposure of mice to gasoline vapor increases the metallothion expression in the brain, lungs and kidney. Histol Histopathol. 2007;22:593-601.

72. Rezaeetalab F, Alamdari DH, Dalili A. Oxidative stress in COPD, pathogenesis and therapeutic views. Rev Clin Med. 2014;1:115-24.

73. Moolenaar RL, Hefflin BJ, Ashley DL, Middaugh JP, Etzel RA. Methyl tertiary butyl ether in human blood exposure to oxygenated fuel in Fairbanks, Alaska. Arch. Environ Health. 1994;49:402-9, https://doi.org/10.1080/00039896.1994.9954993.

74. Hakkola M, Honkasalo ML, Pulkkinen P. Neuropsychological symptoms among tanker drivers exposed to gasoline. Occup Med. 1996;46:125-30.

75. Hakkola M, Honkasalo M-L, Pulkkinen P. Changes in neuropsychological symptoms and moods among tanker drivers exposed to gasoline during a workweek. Occup Med. 1997;47:344-8.

76. Ritchie G, Still K, Alexander W, Nordholm A, Wilson C, Rossie J 3rd, et al. Review of the neurotoxicity risk of selected hydrocarbon fuels. J Toxicol Environ Health B Crit Rev. 2001;4:223-312.

77. Kirrane E, Loomis D, Egeghy P, Nylander-French L. Personal exposure to benzene from fuel emissions among commercial fishers: Comparison of two-stroke, four-stroke and diesel engines. J Expo Sci Environ Epidemiol. 2007;17:151-8.

78. Verelas PN, Syrigoo AI, Kotoulas G, Kapaki EN, Athanasopolou C, Spanaki MV, et al. Cortical atrophy detected by computed tomography in gasoline station attendants. Sci Total Environ. 1999;239:143-9.

79. Rosenberg NL, Spitz MC, Filley CM, Davis KA, Schaumbury HH. Central nervous system effects of chronic toluene abuse-clinical brainstem evoked response and magnetic resonance imaging studies. Neurotoxicol Teratol. 1988;10:489-95.
80. Schwartz E. Proportionate mortality ratio analysis of automobile mechanics and gasoline service stations workers in New Hampshire. Am J Ind Med. 1987;12:91-9.

81. Kumar P, Gupta BN, Pandyn KP, Clerk SH. Behavioral studies in petrol pump workers. Int Arch Occup Environ Health. 1988;61:35-8.

82. Burbacher T. Neurotoxic effect of gasoline and gasoline constituents. Environ Health Perspect. 1993;101:133-41.

83. Tunsaringkarn T, Suwansaksri J, Ketkaew P, Siriwong W. Blood toluene and genotoxicity in gasoline station workers in Bangkok: A preliminary study. J Health Res. 2011;25:161-4.

84. Polakowska B. [Headaches in female workers in the rubber industry exposed to benzene vapor]. Med Pr. 1985;36: 139-44. Polish.

85. Wiwanitkit V. Headaches in subjects occupationally exposed to benzene vapours. J Headache Pain. 2008;9:253-4.

86. Gamberale F, Anwall G, Hultengren M. Exposure to xylene and ethylbenzene. III. Effects on central nervous functions. Scand J Work Environ Health. 1978;4:204-11.

87. Riihimaki V, Savolainen X. Human exposure to m-xylene kinetics and acute effects on the central nervous system. Ann Occup Hyg. 1980;23:411-22.

88. Wooden MA, Hauser R, Liu Y, Smith TJ, Siegel PD, Lewis DM, et al. Molecular markers of acute upper airway inflammation in workers exposed to fuel-oil ash. Am J Respir Crit Care Med. 1998;158:182-7.

89. Kinawy AA. Impact of gasoline inhalation on some neurobehavioral characteristics of male rats. BMC Physiology. 2009;9:21, https://doi.org/10.1186/1472-6793-9-21.

90. Raza H, Qureshi MM, Montaque W. Alteration of glutathione, glutathione S-transferase and lipid per oxidation in muse skin and extracutaneous tissue after topical application of gasoline. Int J Biochem Cell Biol. 1995;27:271-7.

91. Gutteridge JM, Halliwell B. The measurement and mechanism of lipid peroxidation in biological system. Trends Biochem Sci. 1990;15:129-35.

92. Bale AS, Tu Y, Carpenter-Hyland EP, Chandler LJ, Woodward JJ. Alterations in glutamatergic and gabaergic channel 
activity in hippocampal neurons following exposure to the abused inhalant toluene. Neuroscience. 2005;130:197-206, https://doi.org/10.1016/j.neuroscience.2004.08.040.

93. Alsuwaida A. Jet fuel intoxication and acute renal failure. Saudi J Kidney Dis Transpl. 2010;21:150-2.

94. Nwanjo HU, Ojiako OA. Investigation of the potential health hazards of petrol station attendants in Owerri Nigeria. J Appl Sci Environ Manage. 2007;11:197-200.

95. Ravnskov U. Hydrocarbon exposure may cause glomerulonephritis and worsen renal failure: Evidence based on Hill's criteria of causality. QJM. 2000;93:551-6, https://doi. org/10.1093/qjmed/93.8.551.

96. Ravnskov U. Experimental glomerulonephritis induced by hydrocarbon exposure: A systemic review. BMC Nephrol. 2005;6:15-8, https://doi.org/10.1186/1471-2369-6-15.

97. Nanez A, Alejandro NF, Falahatpisheh MH, Kerzee JK, Roths JB, Romos KS. Disruption of glomerular cell-cell and cell-matrix interactions in hydrocarbon nephropathy. Am J Physiol Renal Physiol. 2005;289:1291-303.

98. Edward CW. Toxicology of oil field waste hazards to livestock associated with the petroleum industry. Vet Clin North Am. 1989;5:363-74.

99. Orisakwe E, Njan AA, Afonne OJ, Akumka DD, Orish VN, Udemezue OO. Investigation into the nephrotoxicity of Nigerian bonny light crude oil in albino rats. Int J Environ Res Public Health. 2004;1:106-10.

100. Ovuru SS, Berepubo NA, Nodu MB. Biochemical blood parameters in semi-adult rabbits experimentally fed crude oil contaminated diets. Afr J Biotechnol. 2004;3:343-5.

101. Uboh FE, Akpanbiatu MI, Ekaidem IS, Ebong PE, Umoh IB. Effect of inhalation exposure to gasoline on sex hormones profile in Wistar albino rats. Acta Endocrinol. 2007;3:23-30.

102. Festus OO, Dada FL, Iweka FK, Eyaufe AO, Osagie RN, Osagie EV, et al. Plasma renal functions amongst petrol station attendants in Owerri, South-East Nigeria. Int J Community Res. 2013;2:34-8.

103. Awodele O, Sulayman AA, Akintonwe A. Evaluation of hematological hepatic and renal function of petroleum tanker drivers in Lagos, Nigeria. Afr Health Sci. 2014;14: $178-84$.

104. Ansari-Lari M, Saadat M, Hadi N. Alteration of renal function tests of filling station workers with respect of genetic polymorphisms of GSTM1 and GSTT1. Sci J Hamadan Univ Med Sci. 2004;11:15-21.

105. Uboh FE, Ekaidem IS, Ebong PE, Umoh IB. The hepatoprotective effect of vitamin A against gasoline vapour toxicity in rats. Gastroenterol Res. 2009;2:162-7.

106. Van der Laan G. Chronic glomurulonephritis and organic solvents. A case control study. Int Arch Occup Eviron Health. 1980;47:1-8.

107. Mutti A, Alinovi R, Bergamaschi E, Biagini C, Cavazzini S, Franchini I, et al. Nephropathies and exposure to perchloroethylene in dry-cleaners. Lancet. 1992;340:189-93, https://doi.org/10.1016/0140-6736(92)90463-D.

108. Yaqoob M, Bell GM, Stevenson A, Mason H, Percy DE. Renal impairment with chronic hydrocarbon exposure. Q J Med. 1993;86:165-74.

109. Hotz P. Occupational hydrocarbon exposure and chronic nephropathy. Toxicology. 1994;90:163-283, https://doi.org/ 10.1016/0300-483X(94)90091-4.

110. Klavis G, Drommer W. [Goodpasture syndrome and the effects of benzene]. Arch Toxikol. 1970;26:40-55. German.

111. Kleinknecht D, Morel-Maroger L, Callard P, Adhemar JP, Mahieu P. Anti-glomerular basement membrane nephritis after solvent exposure. Arch Intern Med. 1980;140: 230-2.

112. Viau C, Bernard A, Lauwerys R. A cross sectional survey of kidney function in oil refinery employees. Am J Ind Med. 1987;11:177-87.

113. Yaqoob M, Stevenson A, Mason H, Bell G. Hydrocarbon exposure and tubular damage: Additional factors in the progression of renal failure in primary glomerulonephritis. Q J Med. 1993;86:661-7.

114. Ehrenreich T, Yunis SL, Churg J. Membranous nephropathy following exposure to volatile hydrodcarbons. Environ Res. 1997;14:35-45. 
115. Brautbar N. Industrial solvent and kidney disease. Int J Occup Environ Health. 2004;10:79-83.

116. Ishola DA Jr., Arogundade FA, Sanusi AA, Akinsola A. Association of hydrocarbon exposure with glomerulonephritis in Nigerians: A case control study. Saudi J Kidney Dis Transplant. 2006;17(1):82-9.

117. Bell GM, Gordon AC, Lee P, Diog A, MacDonald MK, Thomson D, et al. Proliferative glomerulonephritis and exposure to organic solvent. Nephron. 1985;40:161-5, https:// doi.org/10.1159/000183476.

118. Caprino L, Togna GI. Potential health effects of gasoline and its constituents: A review of current literature (19901997) on toxicological data. Environ Health Perspect. 1998; 106:115-25.

119. Collingwood KW, Raabe GK, Wong O. An updated cohort mortality study of workers at a northeastern United States petroleum refinery. Int Arch Occup Environ Health. 1996;68:277-88.

120. Loury DJ, Smith-Oliver T, Butterworth BE. Assessment of unscheduled and explicative DNA synthesis in rat kidney cells exposed in vitro or in vivo to unleaded gasoline. Toxicol Appl Pharmacol. 1987;87:127-40.

121. Borghoff SJ, Short BG, Swenberg JA. Biochemical mechanism by pathobiology of $\alpha_{2 u}$-glubulin nephropathy. Annu Rev Pharmacol Toxicol. 1990;30:349-67.

122. Enterline PE. Review of new evidence regarding the relationship of gasoline exposure to kidney cancer and leukemia. Environ Health Perspect. 1993;101:101-3.

123. Ruston L. A 39-year follow-up of the UK refinery and distribution center studies: Results for kidney cancer and leukemia. Environ Health Perspect. 1993;101:77-84.

124. Belpoggi F, Soffritti M, Malton C. Methyl-Tertiary-Butyl Ether (MTBE) - A gasoline additive - Causes testicular and lympho haematopoietic cancers in rats. Toxicol Ind Health. 1995; 11(2):119-49, https://doi.org/10.1177/074823379501100202.

125. Nosko M, Mikhailova A. [Changes in the liver function of workers exposed to petroleum products]. Probl Khig. 1989;14:97-103. Bulgarian.
126. Perez CA, Bosia JD, Cantore MS, Chiera A, Cocozzella IDR, Adrover RE, et al. Liver damage in workers exposed to hydrocarbons. Gastroenterol Hepatol. 2006;29:334-7.

127. Gali RM, Daja A, Mamza YP, Ani GI. Liver enzymes and protein among petrol hawkers and petrol pump attendants in a Nigerian population. Adv Lab Med Int. 2012; 2:123-9.

128. Ogunneye AL, Omoboyowa AD, Sonibare AL, Adebusuyi AJ, Faniran TP. Hepatotoxic and nephrotoxic effects of petroleum fumes on petrol attendants in Ibadan, Nigeria. Nig J Basic Appl Sci. 2014;22:57-62.

129. El-Shakour AA, El-Ebiare AS, Ibrahim YH, Abdel MAE, El-Mekawy AM. Effect of benzene on oxidative stress and the functions of liver and kidney in rats. J Environ Occup Sci. 2015;4:34-9.

130. Momoh J, Oshin TT. Severe hepatotoxicity and nephrotoxicity of gasoline (petrol) on some biochemical parameters in Wistar male albino rats. Am J Biochem. 2015;5:6-14.

131. Uboh FE, Akpanbiatu MI, Eteng PMU, Ebong E, Umoh IB. Toxicological effects of exposure to gasoline vapours in male and female rats. Internet J Toxicol. 2008;4:40-5.

132. Dere E, Ari F. Effect of benzene on liver function in rats (Rattus norvegicus). Environ Monit Assess. 2009;154:23-7.

133. Al-Olayan EM, El-Khadragy MF, Aref AM, Othman MS, Kassab RB, Abdel Moneim AE. The potential protective effect of Physalis peruviana L. against carbon tetrachlorideinduced hepatotoxicity in rats is mediated by suppression of oxidative stress and down regulation of MMP-9 expression. Oxid Med Cell Longev. 2014;2014:381413, https://doi. org/10.1155/2014/381413.

134. Bayraktar NM, Karagözler AA, Bayraktar M, Titretir S, Gozukara EM. Investigation of the blood biochemical status of gas station workers. Toxicol Environ Chem. 2006;88: 587-94, https://doi.org/10.1080/02772240600842383.

135. Odewabi AO, Ogundahunsi OA, Oyalowo M. Effect of exposure to petroleum fumes on plasma antioxidant defense system in petrol attendants. Br J Phamacol Toxicol. 2014;5:83-7. 
136. Daiker DH, Moslen MT, Can JB, Ward JB Jr. Repeated oral benzene exposure alters enzymes involved in benzene metabolism. J Toxicol Environ Health. 1996;48:439-51.

137. George J, Liddle C, Murray M, Byth K, Farrell GC. Pretranslational regulation of cytochrom $\mathrm{P} 450$ gene is responsible for disease changes of individual P450 enzymes among patients with cirrhosis. Biochem Pharmacol. 1995;9:873-81.

138. Yang LQ, Li SJ, Cao YF, Man XB, Yu WF, Wang HY, et al. Different alteration of cytochrome P450 3A4 isoform and its gene expression in the liver of patients with chronic liver diseases. World J Gastroenterol. 2003;9:359-63, https://doi. org/10.3748/wjg.v9.i2.359.

139. Frye RF, Zgheib NK, Matzke GR, Chaves-Gnecco D, Rabinovizt M, Shaikh OS, et al. Liver disease selectively modulates cytochrom P450-mediated metabolism. Clin Pharmacol Ther. 2006;80:235-45.

140. Li G, Hu ZH, Miao XH. [Effects of chronic HBV infection on human hepatic cytochrome P450 3A4]. Zhonghua Yi Xue Za Zhi. 2006;86:2703-6. Chinese.

141. George J, Murray M, Byth K, Farrel GC. Differential alterations of cytochrome $\mathrm{P} 450$ proteins in livers from patients with severe chronic liver disease. Hepatology. 1995;21: $120-8$.

142. Tanaka T, Uchiumi T, Hinoshita E, Inokuchi A, Toh S, Wada M, et al. The human multi drugs resistance protein 2 gene: Functional characterization of the 5-flanking region and expression in hepatic cells. Hepatology. 1999; 30:1507-12, https://doi.org/10.1002/hep.510300617.

143. Mørck HI, Winkel P, Gyntelberg F. Health effects of toluene exposure. Dan Med Bull. 1988;35:196-200.

144. Bener A, Gomes J, Hamouda MFB. Hypertension among workers occupationally exposed to hydrocarbons and organic solvents. J Environ Sci Health. 1996;31:291-303.

145. Kotseva K, Popov T. Study of cardiovascular effects of occupational exposure to organic solvents. Int Arch Occup Environ Health. 1998;71:587-91.

146. Wiwanitkit V. Benzene exposure and hypertension: An observation. Cardiovasc J Afr. 2007;18:264-5.
147. Mohammadi S, Golabadi M, Labbafinejad Y, Pishgahhadian F, Attarchi M. Effects of exposure to mixed organic solvents on blood pressure in non-smoking women working in a pharmaceutical company. Arc Hig Rada Toksikol. 2012;63: 161-9, https://doi.org/10.2478/10004-1254-63-2012-2186.

148. Litovitz TL. Myocardial sensitization following inhalation abuse of hydrocarbons. Occup Med. 1988;3:567-8.

149. Sun Y, Lemitsu M, Shimojo N, Miyauchi T, Amamiya M, Sumi D, et al. 2,4,6-Trinitrotoluene inhibits endothelial nitric oxide syntheses activity and elevates blood pressure in rats. Arch Toxicol. 2005;79:705-10.

150. Landmesser U, Harrison DG, Drexler H. Oxidant stress A major cause of reduced endothehal nitric oxide availability in cardiovascular disease. Eur J Clin Pharmacol. 2006;62:13-9.

151. Künzli N, Tager IB. Air pollution: From lung to heart. Swiss Med Wkly. 2005;135:697-702.

152. Yadav JS, Seth N. Cytogenetical damage in petrol pump workers. Int J Health Georg. 2001;1:145-50.

153. El-Mahdy NM, Radwan NM, Kharoub HS, El-Halawany F. Chromosomal abnormally among petrol station workers occupationally exposed to benzene. Br J Appl Sci Tech. 2015;7:502-13.

154. Rekhadevi PV, Rahman MF, Mahboob M, Grover P. Genotoxicity in filling station attendants expose to petroleum hydrocarbons. Ann Occup Hyg. 2009;54:944-54.

155. Hallare AV, Gervasio MK, Gervasio PL, Acacio-Claro PJ. Monitoring genotoxicity among gasoline station attendants and traffic enforcers in the city of Manila use the micronucleus assay with exfoliated epithelial cells. Environ Monit Assess. 2009;156:331-41.

156. Santiago F, Alves G, Otero UB, Tabalipa MM, Scherrer LR, Kosyakova N, et al. Monitoring of gas station attendants exposure to benzene, toluene, xylene (BTX) using threecolor chromosome painting. Mol Cytogenet. 2014;7:15, https://doi.org/10.1186/1755-8166-7-15.

157. Zhang I, Lan Q, Guo W, Li G, Yang W, Hubbad AE, et al. Use of OctoChrome fluorescence in situ hybridization to 
detect specific aneuploidy among all 24 chromosomes in benzene exposed workers. Chem Biol Interact. 2005;154:117-22.

158. Moro AM, Charao MF, Brucker N, Durgante J, Baierle M, Bubols $\mathrm{G}$, et al. Genotoxicity and oxidative stress in gasoline station attendant. Mutat Res. 2013;754:63-70.

159. Nilsson RI, Nordlinder RG, Tagesson C, Walles S, Järvholm BG. Genotoxic effects in workers exposed to low levels of benzene from gasoline. Am J Ind Med. 1996;30(3):317-24, https://doi.org/10.1002/(SICI)1097-0274 (199609)30:3<317::AID-AJIM10>3.0.CO;2-Z.

160. Singaraju M, Singaraju S, Parawani RN, Wanjari SP. Cytogenetic biomonitoring in petrol station attendants. A micronucleus study. J Cytol. 2012;29:1-5.

161. Wiwanitkit V, Suwansaksri J, Soogarun S. White blood cell sisters' chromatid exchange among a sample of Thai subjects exposed to toluene an observation. Int J Exp Pathol. 2006;87:501-3.

162. Bukvic N, Bavaro P, Elia G, Cassano F, Fanelli M, Guanti G. Sister chromatid exchange (SCE) and micronucleus (MN) frequencies in lymphocytes of gasoline station attendants. Mutat Res. 1998;415:25-33.

163. El Mahdy NM, Radwan NM, Kharoub HS, El-Halawany F. Chromosomal abnormalities among petrol station workers occupationally exposed to benzene. Br J Appl Sci Technol. 2015;7:502-13, https://doi.org/10.9734/BJAST/2015/16369.

164. Bolognesi C, Abbondandolo A, Barale R, Casalone R, Dalprà $\mathrm{L}$, de Ferrari $\mathrm{M}$, et al. Age-related increase of baseline frequencies of sister chromatid exchanges, chromosome aberrations, and micronuclei in human lymphocytes. Cancer Epidemiol Biomark Prev. 1997;6:249-56.

165. Rekhadevi PV, Rahman MF, Mahboob M, Grover P. Genotoxicity in filling station attendants expose to petroleum hydrocarbons. Ann Occup Hyg. 2010;54:944-54.

166. Smidt PG, Friedrich U. The mutagenic effect of benzene, toluene and xylene studied by the SCE technique. Mutat Res. 1978;58:313-36.

167. Delgado ME, Haza AL, Arranz N, Garcia A, Morales P. Dietary polyphones protect against $\mathrm{N}$-nitrosamines and benzo(a)pyrene-induced DNA damage (strand breaks and oxidized purines/pyrimidines) in HepG2 human hepatoma cells. Eur J Nutr. 2008;47:479-90.

168. Atkinson TJ. A review of the role of benzene metabolites and mechanisms in malignant transformation: Summative evidence for a lack of research in nonmyelogenous cancer types. Int J Hyg Environ Health. 2009;212:1-16.

169. Uzma N, Kumar BS, Hazari MA. Exposure to benzene induces oxidative stress, alters the immune response and expression of P53 in gasoline filling workers. Am J Ind Med. 2001;53:1264-70.

170. Arinola OG. Contents of research activities in immunology unit of a tertiary institution in Ibadan Southwestern Nigeria. Br Biotechnol J. 2014;4:400-17.

171. Akinosun OM, Arinola OG, Salimonu LS. Immunoglobulin classes and liver function tests in Nigeria petrol attendants. Indian J Occup Environ Med. 2006;10:58-61.

172. White KL Jr., Peachee VL, Armstrong SR, Twerdok LE, Clark CR, Schreiner CA. Health assessment of gasoline and fuel oxygenate vapors; immunotoxicity evaluation. Regul Toxicol Pharmacol. 2014;70:43-7.

173. Caiazza SS, Ovary Z. Effects of ethanol intake on the immune system of guinea pig. J Stud Alcohol. 1976;37:959-64.

174. Kolb D, Gunderson EK. Alcohol related morbidity among older career navy men. Drug Alcohol Depend. 1982;9: 181-9, https://doi.org/10.1016/0376-8716(82)90043-6.

175. Hsieh GC, Parker RD, Sharma RP, Hughes BJ. Subclinical effects of groundwater contaminate. Effects of repeated oral exposure to combinations of benzene and toluene on immunologic responses in mice. Arch Toxicol. 1990;64:320-8.

176. Fan XH. Effect of exposure to benzene on natural killer (NK) cell activity and interleukin-2 (K-2) production of C57BL/6 mice. Nihon Ika Daigaku Zasshi. 1992;59:393-9, https://doi.org/10.1272/jnms1923.59.393.

177. Farris GM, Robinson SN, Wong BA, Wong VA, Hahn WP, Shah R. Effects of benzene on splenic, thymic, and femoral lymphocytes in mice. Toxicology. 1997;188:137-48, https:// doi.org/10.1016/S0300-483X(96)03606-2. 
178. Dimitrova ND, Kostadinova RY, Marinova SN, Popov TA, Panev TI. Specific immune response in workers exposed to benzene. Int Immunopharmacol. 2005;5:1554-9.

179. Bahadar H, Mostafalou S, Abdollahi M. Current understanding and perspectives on non-cancer health effects of benzene: A global concern. Toxicol Appl Pharmacol. 2014;276:83-94.

180. Shaker DA. Oxidative stress and immuno-globuline levels in workers exposed to cotton dust. Egypt J Occup Med. 2013;36:107-21.

181. Langman JM. Xylene: Its toxicity, measurement of exposure levels, absorption, metabolism and clearance. Pathology. 1994;62:3-19.

182. Gopal KV. Audiological findings in individuals exposed to organic solvents: Case studies. Noise Health. 2008;10: 74-82, https://doi.org/10.4103/1463-1741.44345.

183. Tochetto TM, Quevedo LS, Siqueira MA. Hearing conditions of gas stations attendants. Rev CEFAC. 2013;15:1137-47.

184. Quevedo LS, Tochetto T, Siqueira MA, Machado MS. Auditory brainstem response in gas station attendants. Braz J Otorhinolarygol. 2012;78:63-8.

185. Mergler D, Bowler R, Cone J. Color vision loss among disabled workers with neuropsychological impairment. Neurotoxicol Teratol. 1990;12:669-72, https://doi.org/10. 1016/0892-0362(90)90084-P.

186. Muttray A, Wolff U, Jung D, Konietzko J. Blue-yellow deficiency in workers exposed to flow concentrations of organic solvents. Int Arch Occup Environ Health. 1997;70:407-12, https://doi.org/10.1007/s004200050237.
187. Zavalic M, Mandic Z, Turk R, Bogadi-Sare A, Plavec D, Gomzi M, et al. Assessment of color vision impairment in male workers exposed to toluene generally above occupational exposure limits. Occup Med. 1998;48:175-80.

188. Lacerda EM, Lima MG, Rodrigues AR, Teixeira CE, de Lima LJ, Ventura DF, et al. Psychophysical evaluation of achromatic and chromatic vision of workers chronically exposed to organic solvents. J Environ Public Health. 2012;2012:784390, https://doi.org/10.1155/2012/784390.

189. Costa TL, Barboni MTS, Moura AL, Bonci DM, Gualtieri M, de Lima Silveira LC, et al. Long-term occupational exposure to organic solvents affects color vision, contrast sensitivity and visual fields. PLoS One. 2012;7:e42961, https://doi.org/10.1371/journal.pone.0042961.

190. Sirdah MM, Al Laham NA, El Madhoun RA. Possible health effects of liquefied petroleum gas on workers at filling and distribution stations of Gaza governorates. East Mediterr Health J. 2013;19:289-94.

191. Jia X, Xiao P, Jin X, Shen G, Wang X, Jin T, et al. Adverse effects of gasoline on the skin of exposed workers. Contact Dermatitis. 2002;46:44-7, https://doi.org/10.1034/j.16000536.2002.460109.x.

192. Partanen T, Heikkila P, Hemberg S, Kauppinen T, Moneta G, Ojajcervi A. Renal cell cancer and occupational exposure to chemical agents. Scand J Work Environ Health. 1991;17:231-9.

193. Brandt L, Nilsson PG, Mitelman F. Occupational exposure to petroleum products in men with acute non-lymphocytic leukaemia. Br Med J. 1978;1:553.

This work is available in Open Access model and licensed under a Creative Commons Attribution-NonCommercial 3.0 Poland License - http://creativecommons.org/ licenses/by-nc/3.0/pl/deed.en. 